\title{
$\begin{array}{ll}\text { Research Square } & \text { Preprints are preliminary reports that have not undergone peer review. }\end{array}$ \\ or referenced by the media as validated information.
}

\section{The linkage between CO2, FDI, economic growth, and value-added: A European perspective}

Devesh Singh ( $\nabla$ dev.singh.ece@gmail.com )

Kaposvar University

\section{Research Article}

Keywords: CO2 emission, Foreign Direct Investment, FDI, Gross Value added, economic growth, four-way linkage, service sector, manufacturing sector, agriculture sector, mining and natural resources, Europe, Western Europe, Northern Europe, Southern Europe, Eastern Europe

Posted Date: September 13th, 2021

DOI: https://doi.org/10.21203/rs.3.rs-170999/v2

License: (1) This work is licensed under a Creative Commons Attribution 4.0 International License. Read Full License 


\title{
The linkage between CO2, FDI, economic growth, and value-added:
}

\section{A European perspective}

\begin{abstract}
This article aims to investigate the linkage among $\mathrm{CO} 2$ emissions, Foreign Direct Investment (FDI), economic growth, Gross Value Added (GVA) of different sectors namely agriculture, service, manufacturing, and resource extensive industries including construction sectors in four European regions Eastern Europe (EE), Southern Europe (SE), Northern Europe (NE) and Western Europe (WE). This article uses the 3SLS simultaneous equation estimation during the period of 2000 to 2018 . This study is the extension of seeing the challenges in policy implication in reducing $\mathrm{CO} 2$ emission in technologically rich economies. This article concluded that the causality among variables $\mathrm{CO} 2$ emission, economic growth, FDI, and all four sectors GVA is varied according to the regions. However, the $\mathrm{CO} 2$ emission has bidirectional causality with each industrial sector's GVA.
\end{abstract}

Keywords: CO2 emission; Foreign Direct Investment; FDI; Gross Value added; economic growth; four-way linkage; service sector; manufacturing sector; agriculture sector; mining and natural resources; Europe; Western Europe; Northern Europe; Southern Europe; Eastern Europe.

\section{Introduction}

Academic scholars and policymakers showed increasing interest in how to reduce carbon emissions without sacrificing economic growth. The severity of this issue is described in the (UNIDO, 2019) report. Industrial energy is estimated to increase annually by $1.8 \%$ and $3.1 \%$ further in the next 25 years. This increasing energy demand creates worry-ness due to limited energy resources and seeks sustainable economic growth. Growing industries always seek to improvise the value addition with the limited resource and minimizing the $\mathrm{CO} 2$ emission although it is still a challenge of latest works. The developed countries such as European regions achieved some progress in reducing $\mathrm{CO} 2$ emission, progress through development in technology and innovation and, improving the efficiency of energy and curbing energy use in recent years. However, achieving sustainability along with increasing production requires further effort and investigations to enable the developed economies to achieve such prospective goals.

This study is an attempt to answer the question of how do economic growth, FDI inflows, and sectoral GVAs (agriculture sector, service sector, manufacturing sector, and construction sector) lead to the environmental degradation in Eastern Europe (EE), Southern Europe (SE), Northern Europe (NE), and Western Europe (WE) regions? This research tries to identify which sectors need more attention to achieve sustainability and identify specific policies that can help to develop European region economies in their response to climate change. Concentrating on different sectors agriculture sector, manufacturing sector, service sector, and construction and mining sector. This research inspires by the fact that different sectors agriculture sector, manufacturing sector, service sector, and construction sector need different emissions mitigation actions and energy policies. All together these four sectors produce 33.5\% world's greenhouse gasses (Ritchie \& Roser, 2016). 
Therefore, it is well important to discuss the implication of all of these sectors on environmental degradation.

This work attempts to fill this literature gap by addressing the question of whether the FDI, economic growth, and GVAs are causation of $\mathrm{CO} 2$ emission over the year 2000 to 2018 in European regions. The present study is different from the previous studies in the following way. This paper uses simultaneous-equation modeling to study the four-way linkages between FDI inflows, $\mathrm{CO} 2$ emissions, economic growth, with GVAs (agriculture, mining, manufacturing, and services) sectors in the European region of EE, NE, WE, and SE countries. This four-way linkage enables us to examine the interrelationship between economic growth, FDI, $\mathrm{CO} 2$ emissions, and GVAs at the same time. Specifically, this study uses a model made up of 16 structural equations that allow us to examine the simultaneous influence of (i) the FDI inflows, CO2 emissions, and GVA of agriculture, mining, manufacturing, and services on economic growth; (ii) the economic growth, $\mathrm{CO} 2$ emissions, and GVA of agriculture, mining, manufacturing, and services sector on FDI inflows; and (iii) the economic growth on FDI and GVA of agriculture, mining, manufacturing, and services sector on $\mathrm{CO} 2$ emissions; and (vi) the FDI, $\mathrm{CO} 2$ emissions, and economic growth on GVA of agriculture, mining, manufacturing, and services. Therefore, to the best of the authors' knowledge, this is one of the first studies that simultaneously investigate GVAs of all four sectors in single research for the EE, SE, WE, and NE regions. The, disaggregated study of GVAs sector-wise is important as it can provide a precise relationship between each sector and its impact on $\mathrm{CO} 2$ emission. We considered a homogeneous panel of countries based on their similarity in basic economic structure and geographical proximity, the bifurcation of four groups is according to the (Singh \& Gal, 2020). The findings of this study are immensely important to the design of European Union environmental policy to achieve the pledge of a significant reduction of $\mathrm{CO} 2$ emissions.

The rest of the article is organized as follows: Section 2, provides a critical review of the existing literature. Section 3, data description and explanation of variables and, research methodology of empirical estimation and estimated equations. Section 4, presents the results and discussion. Finally, section 5, discusses the concluding remarks, elaboration of policy implications, limitations, and future recommendations.

\section{Literature}

The relation between $\mathrm{CO} 2$ emission, FDI, GDP per capita, and GVAs has been widely investigated in the last two decades through the various empirical and theoretical literature. But the relationship between $\mathrm{CO} 2$ emission and sectoral GVAs has been a subject of debate and gained importance in the last decade. The literature on $\mathrm{CO} 2$ emission, FDI, economic growth, and industrial sector is classified into three groups. Some studies examine the individual countries (Agboola \& Bekun, 2019; Alamdarlo, 2016; Asom \& Ijirshar, 2016; Prastiyo et al., 2020; Rauf et al., 2018; Samargandi, 2017). Other research focused on income groups (Jebli et al., 2020; Zhang et al., 2019). While some other studies focused on geographic regions (Alam, 2015; Ceylan \& Özkan, 2013; Kołodziejczak, 2020). Finally, some studies presented the overview (Friesenbichler, 2016; H. Liu \& Fan, 2017; Murshed et al., 2020). 


\subsection{FDI and environmental pollution}

The research on the linkage between FDI and environmental pollution is classified into three categories. First, support the pollution haven hypothesis, to avoid costly environmental compliance in their home country from pollution-intensive sectors firms relocate to the weak environmental regulation host country. Therefore, firms significantly increase the overall level of pollution to achieve the desired production. The pollution heaven hypothesis generally exists in the low- and middle-income countries, pollution haven hypothesis exists in the short-run these income group countries in long-run low- and middle-income countries have pollution heaven hypothesis. The reason is that in the beginning foreign multinational corporation tend to improve the efficiency in the limited use of resources to tackle the environmental pollution problem in the host country's domestic enterprises, whereas, on the other hand, they promote the development of the host countries' environmental protection technology via knowledge diffusion, technology spillover, transfer of funds and other ways. The transnational corporations' (TNCs)' investment boost the technological progress and host country's economic development and helps the host country's domestic enterprises to reduce its environmental issues.

Shao, (2018) investigate the effect of FDI on carbon intensity using GMM estimation of the different income levels of the country group using panel data of 188 countries during 1990-2013. Their result supported the pollution halo hypothesis in high-income countries, so, these country groups have to focus on the quality of FDI instead of the amount of FDI inflow. Thus the FDIinvested companies should focus on the introduction of high-tech content while formulating a strict environmental access system and preventing resource-intensive and pollution-intensive investment through modifying the catalog of attracting FDI and adjusting relative preferential policies. Marques \& Caetano, (2020) investigated the relation between FDI and environmental emission in the panel of 21 countries divided on high-income level and low-income level group for a period from 2001 to 2017 using Panel Autoregressive Distributed Lag (ARDL) methodology. They argue that regulation, innovation, and efficiency are important to understand the consequences of FDI inflow. High-income countries were found to benefit from FDI, as it reduced $\mathrm{CO} 2$ emissions, both in the short- and long run, thereby supporting the Pollution Halo Hypothesis. Pollution halo effect in long run multinational transfer environment-friendly technology and maintain universal environmental standards in the host country thus it improves environmental quality.

However, there is a structural difference in high-income countries' economies and the pollution regulation, most of the studies used the single group of higher-income groups. This study fills the gap and contributes to the literature gap by investigating the FDI and environmental emission in a different group of developed economies, where they have basic similar economic structure and geographical proximity.

\subsection{Economic growth and environmental pollution}

Acaravci \& Ozturk, (2010) used the autoregressive distributed lag (ARDL) method to find the causal relationship between $\mathrm{CO} 2$ emission, economic growth, and energy consumption in the European region. The results show the long-run relation between GDP per capita and $\mathrm{CO} 2$ 
emission in Switzerland, Portugal, Italy, Iceland, Greece, Germany, and Denmark. However no long-run relation in Sweden, Norway, Luxemburg, Motherland, UK, France, Belgium, Finland Austria. Manta et al., (2020) estimated the nexus among CO2 emission, economic growth, energy use, and financial development in Central and Eastern European Countries (CEEC) using VECM and Granger causality over the period of 2000 to 2017. The result shows that in the long run energy emission and $\mathrm{CO} 2$ emission have no impact on economic growth while in the short run increasing financial development increases the $\mathrm{CO} 2$ emission and leads to enhanced economic growth. So, the European Union has to promote financial development which will help the countries to reduce the $\mathrm{CO} 2$ emission, focus on the implementation of renewable and lower emission options. Kasperowicz, (2015) examines the relation between CO2 emission and economic growth in 18 European member countries using Error Correction Model (ECM) estimation and finds the negative long-run relation because technological advancement for the production facility, in the long run, reducing the $\mathrm{CO} 2$ emission in Europe. However, for short period increasing economic growth increases the $\mathrm{CO} 2$ emission because the fast production system extensively needs energy.

\subsection{Value-added in different sectors and environmental emission}

Jebli et al., (2020) investigate the relationship between services value-added, industrial valueadded, renewable energy consumption, economic growth, and $\mathrm{CO} 2$ emission worldwide in fourpanel groups of countries lower income, lower middle income, upper middle income, and highincome countries using GMM and Granger Causality test. Their results indicated that industries value-added and economic growth has a positive and significant impact on $\mathrm{CO} 2$ emission in the lower-middle-income countries while economic growth has a negative impact, similarly, uppermiddle-income countries economic growth have a negative impact while industries have a positive impact on $\mathrm{CO} 2$ emission and finally upper-middle-income countries economic growth have positive and significant while services value-added have a negative impact on $\mathrm{CO} 2$ emission. Further, they suggested that eco-friendly project uses of natural resources like wind, water, solar, hydrogen, and nuclear energy countries have to promote and raise the productivity to minimize the carbon emission, another solution is carbon taxation and subsidizing the ecofriendly project investment rely investors on efficient energy sources.

H. Liu \& Fan, (2017) presented value-added accounting (production-based and consumptionbased) system based on $\mathrm{CO} 2$ emission, Main objective of the study investigated the accountability of $\mathrm{CO} 2$ emission originating through human activity, within the boundary of the economic benefits principle. The study was based on bilateral trade of industrial production and variables of $\mathrm{CO} 2$ emission such as $\mathrm{CO} 2$ emission from transport, $\mathrm{CO} 2$ emission from the manufacturing industry and construction, $\mathrm{CO} 2$ emission from electricity and heat production and, $\mathrm{CO} 2$ emission from other sectors. Further, they used these variables to analyze the 3-panel groups based on income level; high-income, low-income, and middle-income group countries. They promote the $\mathrm{CO} 2$ emission-based accounting system based on "consumption" high consumption of good more responsibility and to reduced $\mathrm{CO} 2$ emission advanced country should have to help developing nation by technology transfer to achieve a reduction of $\mathrm{CO} 2$ emission target.

Alam, (2015) examines the value-added influence on GDP in the service sector, agriculture sector, and manufacturing sectors in South Asian countries. Results show that value addition in the 
agriculture sector negatively influences the $\mathrm{CO} 2$ emission while the service and manufacturing sector positively contributing to $\mathrm{CO} 2$ emission. Therefore, the research suggested dependency on the services sector is not the solution to reduce $\mathrm{CO} 2$ emission.

Similarly, Samargandi, (2017) analyses the KEC curve on Saudi-Arabia by considering the technology, sectors value addition in GDP, and volume of production, through the ARDL method. The result shows that the economic growth nurture the $\mathrm{CO} 2$ emission and, value-added growth in industrial and service sector foster the $\mathrm{CO} 2$ emission. However, the value addition in the agriculture sector reduces the $\mathrm{CO} 2$ emission, also, technological advancement help to reduces the $\mathrm{CO} 2$ emission without sacrificing the economic growth.

Rauf et al., (2018) use the ARDL method to find the linkage between industrial value-added, agriculture value-added, service value-added, economic growth, urbanization, financial development, and CO2 emission in China from 1968 to 2016 and, their result shows in the long run and short run industrial, agriculture and services sector value-added have a negative relation with $\mathrm{CO} 2$ emission in China. They recommended that increases carbon taxes, strong laws, and a greenhouse-based economy can is the solution to reduce $\mathrm{CO} 2$ emission. While Xiaoqing \& Jianlan, (2011) find positive relation for the period of 2000 to 2005 and long-term negative relation, between $\mathrm{CO} 2$ emission and industrial value-added from 2006 to 2009. They used the cointegration test to investigate the linkage between $\mathrm{CO} 2$ emission and industrial value-added and, recommended that reform in industrial structure can help to curve down the $\mathrm{CO} 2$ emission.

Through the empirical literature, we observed the relation of $\mathrm{CO} 2$ emission with FDI, economic growth and, service value-added, agriculture value-added, and manufacturing value-added in different regions. In the primary outlook of investigation, empirical literature verified the association among $\mathrm{CO} 2$ emission, FDI, economic growth, and different sectors' value-added in different regions of the world economies. This relation varies for a short-run and long-run period. In addition, the overall results indicate that the GVAs is one of the most important factors to impact $\mathrm{CO} 2$ emission.

Although the sectoral study of GVAs is important for the European Union 2030 pollution reduction goal, little attention has been paid to how the economic growth, FDI, and GVAs of the service sector, manufacturing sector, construction, and natural resources, and, agriculture sectors lead to $\mathrm{CO} 2$ emission. Additionally, the author observed that the previous studies conducted on the relation between $\mathrm{CO} 2$ emission and value-added are dissociated. Therefore, those studies cannot provide efficient policy-oriented and objective-based results and a gap exists in terms of policy guidelines. This study contributes to empirical literature and constitutes a debate on how economic growth, FDI, and GVA in the service sector, manufacturing sector, construction, and natural resources and, agriculture sectors in four-panel (EE, SE, NE, and WE) European regions affect the $\mathrm{CO} 2$ emission. This study is the extension of seeing the challenges in policy implication in reducing $\mathrm{CO} 2$ emission in technologically rich economies.

[Insert Table 1]

\section{Methodology and data description}


Factors like urbanization, inflation, labor, tax, and advancement in technology have a significant effect on CO2 emission. According to L. Liu et al., (2011) increases population expanded urbanization and contribute to an increase in $\mathrm{CO} 2$ emission. Al-mulali et al., (2012) hold that in a world overview study, $84 \%$ of the countries have a positive correlation between urbanization and $\mathrm{CO} 2$ emission. Another aspect of determinants labor participation has an important effect on $\mathrm{CO} 2$ emission. Wei et al., (2018) find labor supply is proportional to the population size and overestimate the $\mathrm{CO} 2$ emission in key aging regions Europe, Russia, United States, and Japan while it underestimates in India. Further Ghazouani et al., (2020) noticed that important factors like an increase in tax influence the $\mathrm{CO} 2$ emission, therefore, in Northern European nations government policies on taxation have a significant impact on $\mathrm{CO} 2$ emission. European nations after 1991 started to implement the taxation policy related to curve CO2 emission. However, the influx of $\mathrm{CO} 2$ pollutant is still persistent and need more innovative reforms and advanced technologies. According to Niu et al., (2011) technology significantly contributes to conduct the clean production development mechanism and reduce $\mathrm{CO} 2$ emission. So, in essence, to investigate the relationships that exist between $\mathrm{CO} 2$ emission, FDI, labor (L), tax (TA), inflation (I), urbanization (U), information and commination technology (ICT), GDPPC (Gross Domestic Product Per Capita) and GVAs in different sectors this paper expressed through following equations. The $\mathrm{CO} 2$ emission function is described by their exogenous variables and present through the following expression (Abdouli et al., 2018; Kahouli, 2018):

$C O 2_{i}=f\left(F D I_{i}, U_{i}, G D P P C_{i}, L_{i}, T A_{i}, I_{i}, I C T_{i}, G V A s_{i}\right)$

Where $\mathrm{i}=1 \ldots \ldots \mathrm{N}, \mathrm{CO} 2_{\mathrm{i}}$ is the damage of environment due to $\mathrm{CO} 2$ emission, $\mathrm{FDI}_{\mathrm{i}}$ is the net inflow of FDI, GDPPC $\mathrm{i}_{\mathrm{i}}$ is the GDP per capita, $\mathrm{I}_{\mathrm{i}}$ is the inflation, $\mathrm{L}_{\mathrm{i}}$ labor force participation rate from 15 to 64 age group, $\mathrm{U}_{\mathrm{i}}$ is urbanization, $\mathrm{TA}_{\mathrm{i}}$ taxes on income profit and gain, $\mathrm{ICT}_{\mathrm{i}}$ is information and commination technology proxy from the number of inhabitants using internet and GVAs $i$ is the value-added sectors of manufacturing, construction and mining, services and, agriculture and fishing.

The log liner form of the equation can be (1) is written as:

$\ln (\mathrm{CO} 2)_{\mathrm{i}}=\beta_{0}+\beta_{1} \ln (\mathrm{FDI})_{\mathrm{i}}+\beta_{2} \ln (\mathrm{U})_{\mathrm{i}}+\beta_{3} \ln (\mathrm{GDPPC})_{\mathrm{i}}+\beta_{4} \ln (\mathrm{L})_{\mathrm{i}}+\beta_{5} \ln (\mathrm{TA})_{\mathrm{i}}+\beta_{6} \ln (\mathrm{I})_{\mathrm{i}}+$ $\beta_{7} \ln (\mathrm{ICT})_{\mathrm{i}}+\beta_{8} \ln (\mathrm{GVAs})_{\mathrm{i}}+\varepsilon_{\mathrm{it}}$

The subscript $\mathrm{i}=1, \ldots ., \mathrm{N}$ denotes the country (the sample of the study is 102 countries), and $\mathrm{t}=1$, ....., T time period from 2000 to $2018, \beta_{0}$ is constant, $\beta_{1}$ to $\beta_{8}$ are the parameters to be estimated

Since this empirical study considers panel data, Eq. (2) can be written in time frame as follow:

$\ln (\mathrm{CO} 2)_{\mathrm{it}}=\beta_{0}+\beta_{1} \ln (\mathrm{FDI})_{\mathrm{it}}+\beta_{2} \ln (\mathrm{U})_{\mathrm{it}}+\beta_{3} \ln (\mathrm{GDPPC})_{\mathrm{it}}+\beta_{4} \ln (\mathrm{L})_{\mathrm{it}}+\beta_{5} \ln (\mathrm{TA})_{\mathrm{it}}+\beta_{6} \ln (\mathrm{I})_{\mathrm{it}}$

$+\beta_{7} \ln (\mathrm{ICT})_{\mathrm{it}}+\beta_{8} \ln (\mathrm{GVAs})_{\mathrm{it}}+\varepsilon_{\mathrm{it}}$

Where $\mathrm{i}=1, \ldots, \mathrm{N}$ and $\mathrm{t}=1, \ldots, \mathrm{T}$ denote country. The four ways linkage among CO2, FDI inflow, economic growth and values added are explained by the following simultaneous equations (Jebli et al., 2020). 


$$
\begin{aligned}
& \ln (\mathrm{CO} 2)_{\mathrm{it}}=\beta_{0}+\beta_{1} \ln \mathrm{FDI}_{\mathrm{it}}+\beta_{2} \ln (\mathrm{U})_{\mathrm{it}}+\beta_{3} \ln (\mathrm{GDPPC})_{\mathrm{it}}+\beta_{4} \ln (\mathrm{L})_{\mathrm{it}}+\beta_{5} \ln (\mathrm{TA})_{\mathrm{it}}+\beta_{6} \ln (\mathrm{I})_{\mathrm{it}}+ \\
& \beta_{7} \ln (\mathrm{ICT})_{\mathrm{it}}+\beta_{8} \ln (\mathrm{GVAs})_{\mathrm{it}}+\varepsilon_{\mathrm{it}} \\
& \ln (\mathrm{FDI})_{\mathrm{it}}=\beta_{0}+\beta_{1} \operatorname{lnCO} 2_{\mathrm{it}}+\beta_{2} \ln (\mathrm{U})_{\mathrm{it}}+\beta_{3} \ln (\mathrm{GDPPC})_{\mathrm{it}}+\beta_{4} \ln (\mathrm{L})_{\mathrm{it}}+\beta_{5} \ln (\mathrm{TA})_{\mathrm{it}}+\beta_{6} \ln (\mathrm{I})_{\mathrm{it}}+ \\
& \beta_{7} \ln (\mathrm{ICT})_{\mathrm{it}}+\beta_{8} \ln (\mathrm{GVAs})_{\mathrm{it}}+\varepsilon_{\mathrm{it}} \\
& \ln (\mathrm{GDPPC})_{\mathrm{it}}=\beta_{0}+\beta_{1} \ln \ln \mathrm{II}_{\mathrm{it}}+\beta_{2} \ln (\mathrm{U})_{\mathrm{it}}+\beta_{3} \ln (\mathrm{CO} 2)_{\mathrm{it}}+\beta_{4} \ln (\mathrm{L})_{\mathrm{it}}+\beta_{5} \ln (\mathrm{TA})_{\mathrm{it}}+\beta_{6} \ln (\mathrm{I})_{\mathrm{it}}+ \\
& \beta_{7} \ln (\mathrm{ICT})_{\mathrm{it}}+\beta_{8} \ln (\mathrm{GVAs})_{\mathrm{it}}+\varepsilon_{\mathrm{it}} \\
& \ln (\mathrm{GVAs})_{\mathrm{it}}=\beta_{0}+\beta_{1} \ln \mathrm{CDI}_{\mathrm{it}}+\beta_{2} \ln (\mathrm{U})_{\mathrm{it}}+\beta_{3} \ln (\mathrm{GDPPC})_{\mathrm{it}}+\beta_{4} \ln (\mathrm{L})_{\mathrm{it}}+\beta_{5} \ln (\mathrm{TA})_{\mathrm{it}}+\beta_{6} \ln (\mathrm{I})_{\mathrm{it}}+ \\
& \beta_{7} \ln (\mathrm{ICT})_{\mathrm{it}}+\beta_{8} \ln (\mathrm{CO} 2)_{\mathrm{it}}+\varepsilon_{\mathrm{it}}
\end{aligned}
$$

Equation 3 to 6 is the common equation for gross value added, where the term GVAs represent the four sectors value-added. So, by changing the GVAs value from AGVA (gross value added of agriculture), CGVA (gross value added of industry involved in construction and mining sector), MGVA (gross value added of the manufacturing sector), and SGVA (gross value added of services sector) one by one in equation 3 to 6 , simultaneous equation of each sector can be obtained. Variable description and terms explanation is given in Table-3. This research uses annual data of the period 2000 to 2018 for 21 European countries, data converted into panel form and grouped into four groups, EE, SE, NE, WE. The data is extracted from World Development Indicators (WDI) and takes a log to make analysis and results in interpretation more viable. A sampling of regions and bifurcation in four panel-group of countries are mentioned in Table 2 and variable description is presented in Table 3. Further, descriptive statics is presented in Table 4. The simultaneous equation approach is used for the econometric estimation and the 3SLS estimation is used for the empirical estimation. Analyze the relationships among the variable is problematic due to the error correlation between variables. Therefore, testing the relation through 3SLS is fulfill our objective requirement because it estimates all parameters in the equation at once and allows correlation between the error terms across the various equations in the number of included equations to be analyzed. So, the 3SLS method is more robust because it addresses the correlation between error and endogeneity, this method is time-tested and used by various researchers (Adewuyi \& Awodumi, 2017; Bakhsh et al., 2017; Bui, 2020; Kahouli, 2018; Mahmoudian et al., 2020). The endogeneity problem is resolved by using a set of instrumental variables. It could be obvious that the endogeneity between the GVAs could occur so, while we considered one GVA for a single sector the other three GVA are considered as endogenous variables. All other right-

hand-side variables are considered explanatory instrumental and exogenous to the system. The LLC unit root test is used in this article to test the stationarity of the variables, shown in Table 5. All variables reject the null hypothesis and accept the alternate hypothesis of the unit root test, which implies all variables used in this article are stationary at the first difference.

Insert Table $[3,4,5]$ here

\section{Results and discussion}

The four-panel group we use in this article is characterized by a similar economic structure, similar transformation of external factors, and similar economic development based on the (Economou, 2019; Sayari et al., 2018; Singh \& Gal, 2020). The author empirically tested the relation among 
CO2, FDI, GDP per capita, and GVAs of four industrial sectors in EE, NE, SE, and WE regions are presented in Table 10, 11, 12, and 13. In this article, there are four models created for each GVA for each region EE, SE, NE, and WE. The performance of the models, significance, and their $\mathrm{R}^{2}$, Chi2, and Root Mean Square Value (RMSE) value is reported in Tables 6, 7, 8, and 9. Where $\mathrm{R}^{2}$ values indicating the model fitted along the regression line and RMSE indicating the accuracy of the model, explaining the occurrence of error and absolute measure of fit. The Chi2 value indicating the significance of relationships among the four dependent variables here the null hypothesis is no relation between the dependent variables. In model summary tables all models are significant with $\mathrm{p}<0.5$, so the null hypothesis is rejected and accepts the alternate hypothesis. It implies the relation among the variables CO2 emission, FDI inflow, GDPPC, and GVAs is significant, we can proceed with models.

$$
\text { Insert summary Table }[6,7,8,9] \text { here }
$$

Addressing the relation between $\mathrm{CO} 2$ emission and value-added in agriculture and its condition regional differences is a noticeable factor. Therefore, Table 9, presents the empirical estimation of the agriculture sector in EE, NE, and WE European regions where we find the four-way linkage while in the SE region relationship of $\mathrm{CO} 2$ with other variables is insignificant so, the three-way linkage is noticed. The significance of AGVA models in Table 9 is in line with the (Ceylan \& Özkan, 2013; Kulyk \& Augustowski, 2020). It is well known that the energy sector plays important role in economic development. The FDI investment can contribute an important role to reduce $\mathrm{CO} 2$ emissions and enhances the agriculture-related industries' production by technology transfer and positively increases the country's economic growth. Long et al., (2018) revealed that technology advancement and innovation negatively affect $\mathrm{CO} 2$ emission and FDI brings new technology and innovation. So, it is possible to reduce the greenhouse emission and increase production through technology advancement and structural changes in the production system and, grow in a sustainable development way. It is also the condition that in long run the opposite relation could be expected, where enhancement in production will not be associate with greenhouse emission. Optimal changes in policy at the individual country level are beneficial not economically but also socially such as the association between academia and agriculture. Labor is the most important factor that contributes to the four-way linkage of GVA-A. The positive approach of labor training is a necessary condition for the adaptation and implementation of new technology. Similar to the argument Pishgar-Komleh et al., (2012); Mobtaker et al., (2013) reported that advanced machinery and trained labor increase production and save the energy consumption in the production system which reduces the $\mathrm{CO} 2$ emission. The rationalization of employment in agriculture in Europe supports sustainability and economic development.

The relation between FDI and $\mathrm{CO} 2$ emission is positive in EE and WE region, negative in the NE region, and has no significance in the SE region. The results of the negative and positive association between FDI and CO2 emission are in line with the (Huang et al., 2019; Shao, 2018). According to Pazienza, (2015) suggestion, the sign between FDI on CO2 emission is dependent on the productivity specialization of the country and the country's competitive advantage. The insignificance of FDI and CO2 emission in the SE region is understood by the isolated phenomena, it implies other sectors have a greater impact compared to agriculture, which means these 
phenomena are influenced by the other factors (Atici, 2012; Demena \& Afesorgbor, 2020; Wang et al., 2020). Further, the increase of FDI inflow by $1 \%$ tends to raise the $\mathrm{CO} 2$ emission $3.23 \%$ in $\mathrm{EE}$ and $5 \%$ increase tends to $0.43 \%$ in $\mathrm{WE}$, while in $\mathrm{NE}$ this association is negative so the increase of FDI inflow by $0.1 \%$ decrease the $\mathrm{CO} 2$ emission $-1.37 \%$. Therefore, in the NE region, FDI inflow sufficiently brings technological advancement and innovation to reduce $\mathrm{CO} 2$ emission.

Further GDP per capita has a significant relation with all variables FDI, CO2, and GVA-A, except, FDI inflow and economic growth in the SE region. This insignificant result is consistent with (Alvarado et al., 2017). Another side, the relation between GDP per capita and CO2 emission has a negative association in all regions because in the long-run development of new technology to reduce $\mathrm{CO} 2$ emission production system produces the same product with a lower level of carbon emission while, in the short-run GDP and $\mathrm{CO} 2$ emission is positive because the rapid increase in production can be achieved due to large intensive energy used compared to previous consumption of energy with lower production, capacity increase CO2 emission increase (Kasperowicz, 2015).

\section{Insert Table [9] here}

The empirical estimation for SGVA sector industries is shown in Table 10. The EE region countries' service sector are more positively contribute to $\mathrm{CO} 2$ emission compare to the other three European panel groups, which have an almost similar effect on carbon emission because according to Kołodziejczak, (2020) less affluent countries in Europe, a greater number of workforces related to the agriculture while in high affluent countries a smaller number of workforces related to the agriculture sector, so the high GVA is generated through the secondary sectors (industry) and tertiary sectors (service).

The SGVA sector industries have a $0.1 \%$ significance level and positive relation with $\mathrm{CO} 2$ emission in all four regions of Europe, this result is similar to the (Jebli et al., 2020; Murshed et al., 2020). The relation between CO2 emission and FDI inflow has $0.1 \%$ significant relation in SE region it implies $0.1 \%$ increase in FDI inflow $\mathrm{CO} 2$ emission rise $4.01 \%$, significant and negative relation in NE region 1\% increase in FDI inflow CO2 emission decreases $1.059 \%$ and insignificant relation in EE and WE region. While GDP per capita has $0.1 \%$ significant and negative association with $\mathrm{CO} 2$ emission in all four European regions this result is similar to the (Kasperowicz, 2015). Because adaptation of low carbon technologies takes time to reach the same production level with lesser $\mathrm{CO} 2$ emission. Further SGVA and $\mathrm{CO} 2$ emission results are highly significant, thus every $0.1 \%$ rise in service sectors GVA tends to $1.276 \%$ rise of $\mathrm{CO} 2$ emission in EE region while in SE, $\mathrm{NE}$, and WE regions it increases approximately $0.9 \%$ (one point decimal place).

\section{Insert Table [10] here}

Regarding the MGVA panel, estimation results in Table 11 indicating that all four European regions manufacturing sectors are the highly significant and positive contributors of $\mathrm{CO} 2$ emission. It is also noticeable that comparing to all four European regions $\mathrm{EE}$ has a high coefficient value for every $0.1 \%$ rise of GVA of manufacturing sectors, $\mathrm{CO} 2$ value increases $1.42 \%$. This result is similar to the (Jebli et al., 2020). Although it is admissible that the manufacturing value-added is the most impactful driver of $\mathrm{CO} 2$ emission, up-gradation of technology through innovations, industries can improve the efficiency of the production system and reduces the carbon emission 
(Li et al., 2019). Although CO2 emission increases rapidly due to cheaper polluting resources Central and Eastern European (CEE) countries have had high CO2 emission per capita since 1980 this carbon emission is continuously decreasing. However, compared to other technologically advanced European regions such as WE countries $\mathrm{CO} 2$ emission per capita is still high in CEE countries (Atici, 2009). Thus, the CEE regions need FDI which brings innovation and technology advancement therefore, FDI inflow can play an important role to address this issue, based on previous empirical literature. In this research results, a 1\% rise of FDI inflow tends to increases the $4.04 \%$ of $\mathrm{CO} 2$ emission in EE regions. Another step of reducing the $\mathrm{CO} 2$ emission can be to increase the GDP per capita, the results show the significant and negative association between GDP per capita and $\mathrm{CO} 2$ emission in EE, WE, and NE region increase in per capita income decreases the carbon emission this significant result is supported by the (Alvarado et al., 2017; Kasperowicz, 2015). Therefore every $0.1 \%$ increase of GDP per capita reduces the CO2 emission $1.56 \%, 1.12 \%$, and $1.62 \%$ in EE, NE, and WE regions respectively. Further MGVA has a significant relation with all variables FDI, CO2, and GDP per capita except, FDI inflow and MGVA in EE regions.

\section{Insert Table [11] here}

Results related to the CGVA are shown in Table 12, representing the resource extensive industries including construction, mining, electricity, water, and gas. The Table 12 results demonstrate that GAV-C has a $0.1 \%$ significant and positive impact on $\mathrm{CO} 2$ emission in all four panel-group EE, SE, NE, and WE regions. This result is similar to the (Murshed et al., 2020). However, the impact of CGVA on $\mathrm{CO} 2$ emission is very less in all European countries possibly because the European region is a group of advanced developed countries where construction and mining are very rare compare to developing nations where construction is at peak. Further FDI has a significant and positive impact on $\mathrm{CO} 2$ in $\mathrm{EE}, \mathrm{SE}$, and $\mathrm{WE}$ region and a negative impact in the $\mathrm{NE}$ region concerning CGVA. Every 5\% rise of FDI inflow tends to increase CO2 emission 4.44\%, $1 \%$ rise in FDI inflow tends to increase CO2 emission $10.04 \%$ in SE and $0.85 \%$ in WE. The significance of the model of CGVA is supported by (Alcántara \& Padilla, 2006; Murshed et al., 2020; Zhang et al., 2019). We observed the four-way linkage in terms of CGVA which is significant with variables CO2, FDI inflow, and GDP per capita in all regions except the relation between FDI inflow in EE regions. Furthermore, we observed the heterogeneity in the relation between the GDP per capita and FDI inflow; insignificant relation in EE regions, significant but negative relation in SE regions, insignificant relation in NE regions, and a significant and positive association in WE regions. This result is similar to the (Bačić et al., 2004; Bermejo Carbonell \& Werner, 2018; Simionescu, 2016). The insignificant effect of economic growth on FDI inflow strives to be positive by developing a strong domestic financial system- FDI is more beneficial to advanced economies (Hermes \& Lensink, 2003).

Insert Table [12] here

The summary, depiction of relationship and causality of the variable is reported in Figure 1 and 2. Where arrows end indicating the direction of the causality.

Insert Figure [1 and 2] 


\section{Conclusion}

This study analyses the four-way linkage among CO2 emission, FDI inflow, GDP per capita, and value-added in four sectors AGVA, SGVA, MGVA, and CGVA in four European regions EE, WE, SE, and NE over the period of 2000 to 2018 and data have been used from the WDI database. To do this simultaneous equation approach has been used with the 3SLS estimation technique.

The result of panel groups EE, NE, SE, and WE regions shows that the $\mathrm{CO} 2$ emission has bidirectional causality with each industrial sector AGVA, SGVA, MGVA, and CGVA. Therefore, this article finds homogeneity in the relation between $\mathrm{CO} 2$ and GAVs of industrial sectors.

There is a bidirectional relation between $\mathrm{CO} 2$ emission and economic growth in $\mathrm{EE}, \mathrm{SE}, \mathrm{NE}$, and WE regions for industrial sector GVA-A, SGVA, and CGVA, while there is no association between $\mathrm{CO} 2$ emission and economic growth when we considered the manufacturing GVA in SE region.

The relation between $\mathrm{CO} 2$ emission and FDI we find the heterogeneous results. In the scenario of the GVA agriculture sector EE, NE, and WE region countries have bidirectional causality while $\mathrm{SE}$ region result shows no relation. For the case of the services sector, GVA bidirectional causality in $\mathrm{NE}$ and $\mathrm{SE}$ regions while no relation in EE and WE regions. Further manufacturing sector GVA there is bidirectional relation in $\mathrm{EE}, \mathrm{NE}$, and $\mathrm{WE}$ regions and no relation for $\mathrm{SE}$ region. Furthermore, with consideration of CGVA sectors, we find bidirectional relations in all sub-group $\mathrm{EE}, \mathrm{SE}, \mathrm{NE}$, and WE regions. In the European region, it is well known that better policy, management, and advanced technology may play a critical role to curve $\mathrm{CO} 2$ emissions. Hence, in that case through FDI we can achieve zero or negative effects on $\mathrm{CO} 2$ emission.

Therefore, there is heterogeneity in the literature to make uniform consciousness about the $\mathrm{CO} 2$ and FDI relations. Adaptation of better policy, management, and advanced technology may play a critical role to curve $\mathrm{CO} 2$ emissions. Hence, in that case through FDI we can achieve zero or negative effects on $\mathrm{CO} 2$ emission.

The result of the relation between FDI inflow and economic growth is also heterogeneous. There is no relation between FDI and economic growth in EE, SE, NE, and WE region for the case of sector GVA. In the case of GVA of agriculture sector EE, NE, and WE bidirectional relation while no causality in SE region.

The results of this article help the policymakers to understand and grasp the complexity of the relation among the $\mathrm{CO} 2$ emission, FDI inflow, economic growth, and GVA of different sectors in the European region. Therefore, the findings of this study have potential importance for policymaking to tackle the $\mathrm{CO} 2$ emission in different industrial sectors. This article concluded that the causality among this research variable depends on the regions, indicating that it is impossible to create universal policy and recommendations for European regions. Therefore, to make pollution free economic development decision-makers (such as European Union) have to draft policies that should have to consider regional factors and coherent with industrial sectors which will help to reduce the $\mathrm{CO} 2$ emission without sacrificing the economic growth because in our results factors like labor, urbanization, taxes, and internet and telecommunication variable 
influence $\mathrm{CO} 2$ emission influence heterogeneously according to the regions and industry-specific in Europe. Along with its merits, this article has some limitations. This article panel-groups are limited to the group of countries and didn't focus on country-specific; it leads the future research. Finally, it will be interesting to find out these relations at the country level.

\section{Discloser statement}

There is no potential conflict of interest is reported by the author.

Funding agency: Not Applicable

Ethical Approval: Not applicable

Consent to Participate: Not applicable

Consent to Publish: Not applicable

Authors Contributions: Not applicable Sole Author

Availability of data and materials: World Bank data open-source data

\section{References}

Abdouli, M., Kamoun, O., \& Hamdi, B. (2018). The impact of economic growth, population density, and FDI inflows on CO2 emissions in BRICTS countries: Does the Kuznets curve exist? Empirical Economics, 54(4), 1717-1742. https://doi.org/10.1007/s00181-017-1263-0

Acaravci, A., \& Ozturk, I. (2010). On the relationship between energy consumption, CO2 emissions and economic growth in Europe. Energy, 35(12), 5412-5420. https://doi.org/10.1016/j.energy.2010.07.009

Adewuyi, A. O., \& Awodumi, O. B. (2017). Biomass energy consumption, economic growth and carbon emissions: Fresh evidence from West Africa using a simultaneous equation model. Energy, 119, 453-471. https://doi.org/10.1016/j.energy.2016.12.059

Agboola, M. O., \& Bekun, F. V. (2019). Does agricultural value added induce environmental degradation? Empirical evidence from an agrarian country. Environmental Science and Pollution Research, 26, 27660-27676. https://doi.org/10.1007/s11356-019-05943-z

Al-mulali, U., \& Foon Tang, C. (2013). Investigating the validity of pollution haven hypothesis in the gulf cooperation council (GCC) countries. Energy Policy, 60, 813-819. https://doi.org/10.1016/j.enpol.2013.05.055

Al-mulali, U., Normee, C., Che, B., \& Gholipour, H. (2012). Exploring the bi-directional long run relationship between urbanization, energy consumption, and carbon dioxide emission. Energy, 46(1), 156-167. https://doi.org/10.1016/j.energy.2012.08.043

Alam, J. (2015). Impact of Agriculture , Industry and Service Sector's Value Added in the GDP on CO2 Emissions of Selected South Asian Countries. World Review of Business Research, 5(2), 39-59.

Alamdarlo, H. N. (2016). Water consumption, agriculture value added and carbon dioxide emission in Iran, environmental Kuznets curve hypothesis. International Journal of Environmental Science and Technology, 13, 2079-2090. https://doi.org/10.1007/s13762016-1005-4

Alcántara, V., \& Padilla, E. (2006). An input-output analysis of the "key" sectors in CO2 emissions from a production perspective: an application to the Spanish economy (No. 1). https://dialnet.unirioja.es/servlet/articulo?codigo $=1997740$ 
Alvarado, R., Iñiguez, M., \& Ponce, P. (2017). Foreign direct investment and economic growth in Latin America. Economic Analysis and Policy, 56(December), 176-187. https://doi.org/https://doi.org/10.1016/j.eap.2017.09.006

Asom, S. T., \& Ijirshar, V. U. (2016). Impact of Agriculture Value Added on the Growth of Nigerian Economy. Nigerian Journal of Management Sciences, 5(1), 238-245.

Atici, C. (2009). Carbon emissions in Central and Eastern Europe: environmental Kuznets curve and implications for sustainable development. Sustainable Development, 17(3), 155-160. https://doi.org/https://doi.org/10.1002/sd.372

Atici, C. (2012). Carbon emissions, trade liberalization, and the Japan-ASEAN interaction: A group-wise examination. Journal of the Japanese and International Economies, 26(1), 167178. https://doi.org/10.1016/j.jjie.2011.07.006

Bačić, K., Račić, D., \& Ahec Šonje, A. (2004). FDI and economic growth in Central and Eastern Europe: Is there a link? In Zagreb School of Economics and Management (No. 83136).

Bakhsh, K., Rose, S., Ali, M. F., Ahmad, N., \& Shahbaz, M. (2017). Economic growth, CO2 emissions, renewable waste and FDI relation in Pakistan: New evidences from 3SLS. Journal of Environmental Management, 196, 627-632. https://doi.org/10.1016/j.jenvman.2017.03.029

Bengochea-morancho, A., Higón-tamarit, F., \& Martínez-Zarzoso, I. (2001). Economic Growth and $\mathrm{CO} 2$ Emissions in the European Union. Environmental and Resource Economics, 19, $165-172$.

Bermejo Carbonell, J., \& Werner, R. A. (2018). Does Foreign Direct Investment Generate Economic Growth? A New Empirical Approach Applied to Spain. Economic Geography, 94(4), 425-456. https://doi.org/https://doi.org/10.1080/00130095.2017.1393312

Bui, D. T. (2020). Transmission channels between financial development and CO2 emissions: A global perspective. Heliyon, 6(11), e05509. https://doi.org/10.1016/j.heliyon.2020.e05509

Ceylan, R. F., \& Özkan, B. (2013). Agricultural value added and economic growth in the European union accession process. New Medit, 12(4), 62-71.

Chandran, V. G. R., \& Tang, C. F. (2013). The impacts of transport energy consumption, foreign direct investment and income on CO2 emissions in ASEAN-5 economies. In Renewable and Sustainable Energy Reviews (Vol. 24, pp. 445-453). Elsevier. https://doi.org/10.1016/j.rser.2013.03.054

Choi, E., Heshmati, A., \& Cho, Y. (2010). An Empirical Study of the Relationships between An Empirical Study of the Relationships between CO2 Emissions , Economic Growth and Openness (Issue 5304).

Demena, B. A., \& Afesorgbor, S. K. (2020). The effect of FDI on environmental emissions: Evidence from a meta-analysis. Energy Policy, 138(xxxx), 111192. https://doi.org/10.1016/j.enpol.2019.111192

Economou, F. (2019). Economic freedom and asymmetric crisis effects on FDI inflows: The case of four South European economies. Research in International Business and Finance, 49, 114-126. https://doi.org/10.1016/j.ribaf.2019.02.011 
Friesenbichler, K. S. (2016). Innovation, Competition and Productivity: Firm Level Evidence for Eastern Europe and Central Asia. SSRN Electronic Journal. https://doi.org/10.2139/ssrn.2764249

Ghazouani, A., Xia, W., \& Jebli, M. Ben. (2020). Exploring the Role of Carbon Taxation Policies on CO2 Emissions : Contextual Evidence from Tax Implementation and NonImplementation European Countries. Sustainability, 12(20), 8680. https://doi.org/https://doi.org/10.3390/su12208680

Hermes, N., \& Lensink, R. (2003). Foreign direct investment, financial development and economic growth. Journal of Development Studies, 40(1), 142--163. https://doi.org/https://doi.org/10.1080/00220380412331293707

Huang, Y., Chen, X., Zhu, H., Huang, C., \& Tian, Z. (2019). The Heterogeneous Effects of FDI and Foreign Trade on CO 2 Emissions: Evidence from China. Mathematical Problems in Engineering, 2019, 1-14. https://doi.org/https://doi.org/10.1155/2019/9612492

Jardón, A., Kuik, O., \& Tol, R. S. J. (2017). Economic growth and carbon dioxide emissions: An analysis of Latin America and the Caribbean. Atmosfera, 30(2), 87-100. https://doi.org/10.20937/ATM.2017.30.02.02

Jebli, M. Ben, Farhani, S., \& Guesmi, K. (2020). Renewable energy , CO2 emissions and value added : Empirical evidence from countries with different income levels. Structural Change and Economic Dynamics, 1-9. https://doi.org/10.1016/j.strueco.2019.12.009

Kahouli, B. (2018). The causality link between energy electricity consumption, CO2 emissions, R\&D stocks and economic growth in Mediterranean countries (MCs). Energy, 145, 388399. https://doi.org/10.1016/j.energy.2017.12.136

Kasperowicz, R. (2015). Economic growth and CO2 emissions: The ECM analysis. Journal of International Studies, 8(3), 91-98. https://doi.org/10.14254/2071-8330.2015/8-3/7

Kivyiro, P., \& Arminen, H. (2014). Carbon dioxide emissions, energy consumption, economic growth, and foreign direct investment : Causality analysis for Sub-Saharan Africa. Energy, 74, 595-606. https://doi.org/10.1016/j.energy.2014.07.025

Kołodziejczak, W. (2020). Employment and gross value added in agriculture versus other sectors of the European Union Economy. Sustainability (Switzerland), 12(14). https://doi.org/10.3390/su12145518

Kulyk, P., \& Augustowski, L. (2020). Conditions of the occurrence of the environmental kuznets curve in agricultural production of central and eastern european countries. Energies, 13(20), 1-22. https://doi.org/10.3390/en13205478

Li, Z., Shao, S., Shi, X., Sun, Y., \& Zhang, X. (2019). Structural Transformation of Manufacturing, Natural Resource Dependence, and Carbon Emissions Reduction: Evidence of a Threshold Effect from China. Journal of Cleaner Production, 206(January). https://doi.org/10.1016/j.jclepro.2018.09.241

Liu, H., \& Fan, X. (2017). Value-Added-Based Accounting of CO2 Emissions : A MultiRegional Input-Output Approach. Sustainability, 9(2220), 1-18. https://doi.org/10.3390/su9122220

Liu, L., Wu, G., Wang, J., \& Wei, Y. (2011). China's carbon emissions from urban and rural 
households during 1992 -2007. Journal of Cleaner Production, 19(15), 1754-1762. https://doi.org/10.1016/j.jclepro.2011.06.011

Long, X., Luo, Y., Wu, C., \& Zhang, J. (2018). Correction to: The influencing factors of CO2 emission intensity of Chinese agriculture from 1997 to 2014 (Environ Sci Pollut Res, 10.1007/s11356-018-1549-6). Environmental Science and Pollution Research, 25(13), 13102. https://doi.org/10.1007/s11356-018-1706-y

Mahmoudian, F., Lu, J., Yu, D., Nazari, J. A., \& Herremans, I. M. (2020). Inter-and intraorganizational stakeholder arrangements in carbon management accounting. British Accounting Review, 100933. https://doi.org/10.1016/j.bar.2020.100933

Manta, A. G., Florea, N. M., Maria, R., Popescu, J., Cîrciumaru, D., \& Doran, M. D. (2020). The Nexus between Carbon Emissions, Energy Use, Economic Growth and Financial Development : Evidence from Central and Eastern European Countries. Sustainability, 12(7747).

Marques, A. C., \& Caetano, R. (2020). The impact of foreign direct investment on emission reduction targets: Evidence from high- and middle-income countries. Structural Change and Economic Dynamics, 55(January), 107-118. https://doi.org/10.1016/j.strueco.2020.08.005

Mert, M., Bölük, G., \& Çağlar, A. E. (2019). Interrelationships among foreign direct investments , renewable energy, and CO 2 emissions for different European country groups : a panel ARDL approach. Environmental Science and Pollution Research, 26, 1-16. https://doi.org/https://doi.org/10.1007/s11356-019-05415-4

Mobtaker, H. G., Taki, M., Salehi, M., \& Shahamat, E. Z. (2013). Application of nonparametric method to improve energy productivity and $\mathrm{CO} 2$ emission for barley production in Iran. Agricultural Engineering International: CIGR Journal, 15(4), 84-93.

Murshed, M., Nurmakhanova, M., Elheddad, M., \& Ahmed, R. (2020). Value addition in the services sector and its heterogeneous impacts on $\mathrm{CO} 2$ emissions: revisiting the $\mathrm{EKC}$ hypothesis for the OPEC using panel spatial estimation techniques. Environmental Science and Pollution Research, 27(31), 38951-38973. https://doi.org/10.1007/s1 1356-020-09593-4

Niu, S., Ding, Y., Niu, Y., Li, Y., \& Luo, G. (2011). Economic growth, energy conservation and emissions reduction: A comparative analysis based on panel data for 8 Asian-Pacific countries. Energy Policy, 39(4), 2121-2131. https://doi.org/10.1016/j.enpol.2011.02.003

Omri, A., Khuong, D., \& Rault, C. (2014). Causal interactions between CO2 emissions , FDI , and economic growth : Evidence from dynamic simultaneous-equation models. Economic Modelling, 42(2014), 382-389. https://doi.org/10.1016/j.econmod.2014.07.026

Omri, A., Nguyen, D. K., \& Rault, C. (2014). Causal interactions between CO2 emissions , FDI , and economic growth: Evidence from dynamic simultaneous-equation models Causal interactions between CO2 emissions, FDI, and econom- ic growth : Evidence from dynamic simultaneous-equation models (No. 82504; Issue 82504). https://mpra.ub.unimuenchen.de/82504/

Pazienza, P. (2015). The relationship between CO2 and Foreign Direct Investment in the agriculture and fishing sector of OECD countries: Evidence and policy considerations. Intellectual Economics, 9(1), 55-66. https://doi.org/10.1016/j.intele.2015.08.001 
Pishgar-Komleh, S. H., Ghahderijani, M., \& Sefeedpari, P. (2012). Energy consumption and CO 2 emissions analysis of potato production based on different farm size levels in Iran. Journal of Cleaner Production, 33, 183-191. https://doi.org/10.1016/j.jclepro.2012.04.008

Prastiyo, S. E., Irham, Hardyastuti, S., \& Jamhari. (2020). How agriculture, manufacture, and urbanization induced carbon emission? The case of Indonesia. Environmental Science and Pollution Research, 27(33), 42092-42103. https://doi.org/10.1007/s11356-020-10148-w

Rauf, A., Zhang, J., Li, J., \& Amin, W. (2018). Structural changes, energy consumption and carbon emissions in China: Empirical evidence from ARDL bound testing model. Structural Change and Economic Dynamics, 47, 194-206.

https://doi.org/10.1016/j.strueco.2018.08.010

Ritchie, H., \& Roser, M. (2016). Sector by sector: where do global greenhouse gas emissions come from? Oxfort Martin School. https://ourworldindata.org/emissions-by-sector

Samargandi, N. (2017). Sector value addition, technology and CO2 emissions in Saudi Arabia. Renewable and Sustainable Energy Reviews, 78(April), 868-877. https://doi.org/10.1016/j.rser.2017.04.056

Sayari, N., Sari, R., \& Hammoudeh, S. (2018). The impact of value added components of GDP and FDI on economic freedom in Europe. Economic Systems, 42(2), 282-294. https://doi.org/10.1016/j.ecosys.2017.03.003

Shao, Y. (2018). Does FDI affect carbon intensity? New evidence from dynamic panel analysis. International Journal of Climate Change Strategies and Management, 10(1), 27-42. https://doi.org/10.1108/IJCCSM-03-2017-0062

Simionescu, M. (2016). The relation between economic growth and foreign direct investment during the economic crisis in the European Union. Zbornik Radova Ekonomskog Fakulteta u Rijeci: ‘casopis Za Ekonomsku Teoriju i Praksu, 34(1), 187-213. https://doi.org/https://doi.org/10.18045/zbefri.2016.1.187

Singh, D., \& Gal, Z. (2020). Economic Freedom and its Impact on Foreign Direct Investment: Global Overview. Review of Economic Perspectives, 20(1), 73-90. https://doi.org/10.2478/revecp-2020-0004

UNIDO. (2019). Industrial energy efficiency and climate change. https://www.unido.org/ourfocus/safeguarding-environment/clean-energy-access-productive-use/industrial-energyefficiency-and-climate-change

Wang, M. L., Wang, W., Du, S. Y., Li, C. F., \& He, Z. (2020). Causal relationships between carbon dioxide emissions and economic factors: Evidence from China. Sustainable Development, 28(1), 73-82. https://doi.org/10.1002/sd.1966

Wei, T., Zhu, Q., \& Glomsrød, S. (2018). How Will Demographic Characteristics of the Labor Force Matter for the Global Economy and Carbon Dioxide Emissions? Ecological Economics, 147(February 2017), 197-207. https://doi.org/10.1016/j.ecolecon.2018.01.017

Xiaoqing, Z., \& Jianlan, R. (2011). The Relationship between Carbon Dioxide Emissions and Industrial Structure Adjustment for Shandong Province. Energy Procedia, 5, 1121-1125. https://doi.org/10.1016/j.egypro.2011.03.197

Zakarya, G. Y., Mostefa, B., Abbes, S. M., \& Seghir, G. M. (2015). Factors Affecting CO2 
Emissions in the BRICS Countries: A Panel Data Analysis. Procedia Economics and Finance, 26(May), 114-125. https://doi.org/10.1016/s2212-5671(15)00890-4

Zhang, Y., Chen, X., Wu, Y., Shuai, C., \& Shen, L. (2019). The environmental Kuznets curve of $\mathrm{CO} 2$ emissions in the manufacturing and construction industries : A global empirical analysis. Environmental Impact Assessment Review, 79(June), 1-13. https://doi.org/10.1016/j.eiar.2019.106303 
Figure-1, Relation summary of AGVAand SGVA.

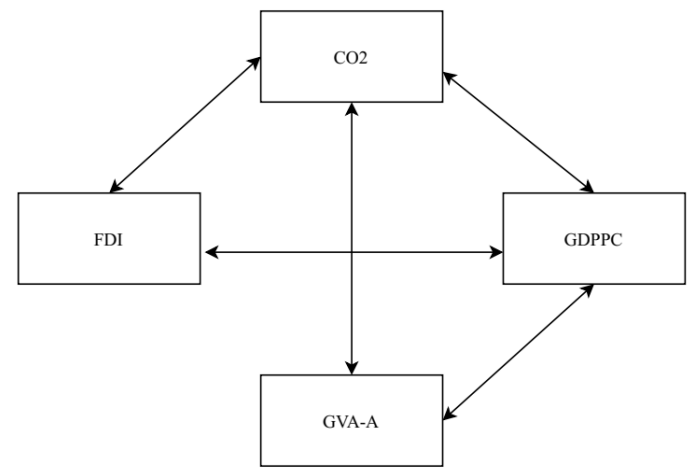

EE
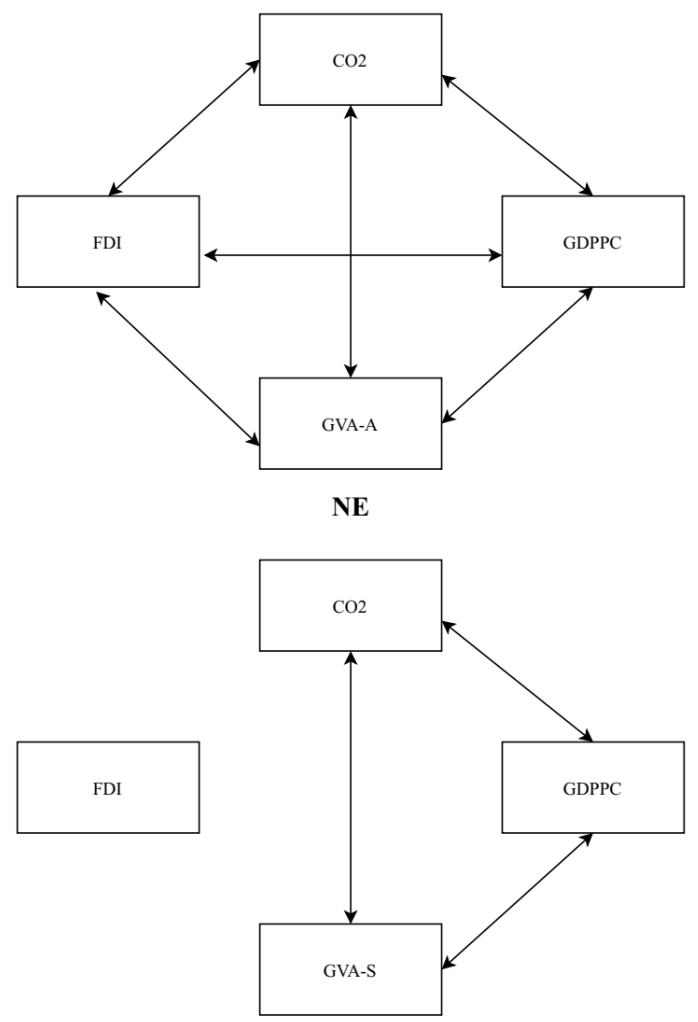

EE

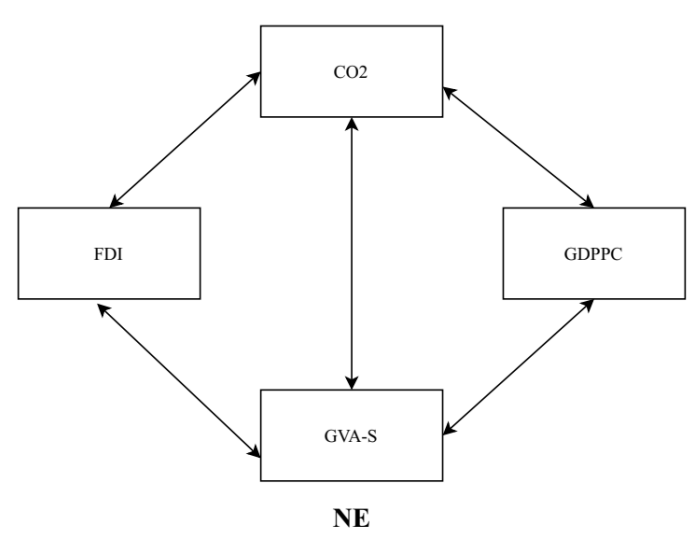

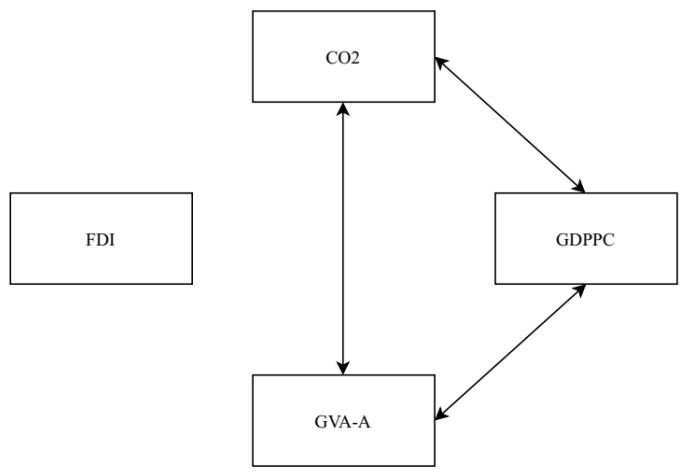

SE

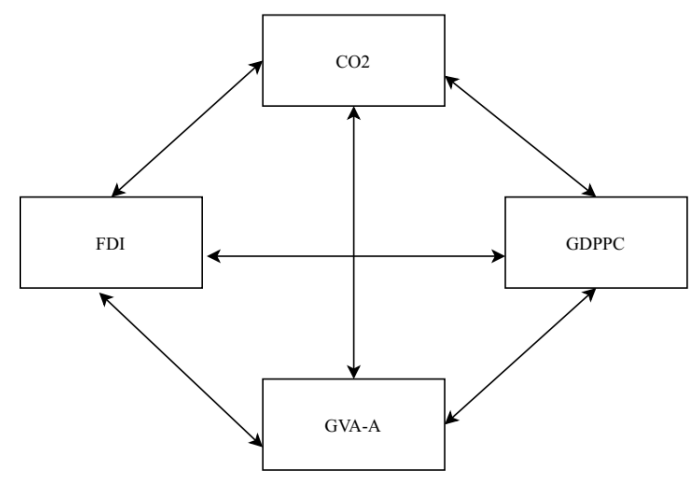

WE

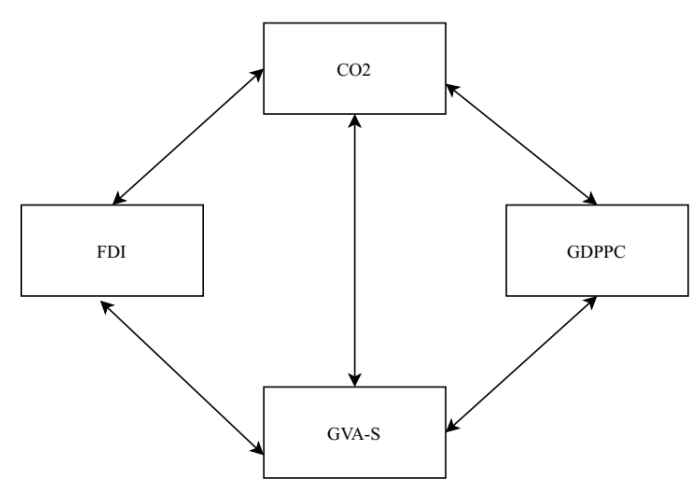

SE

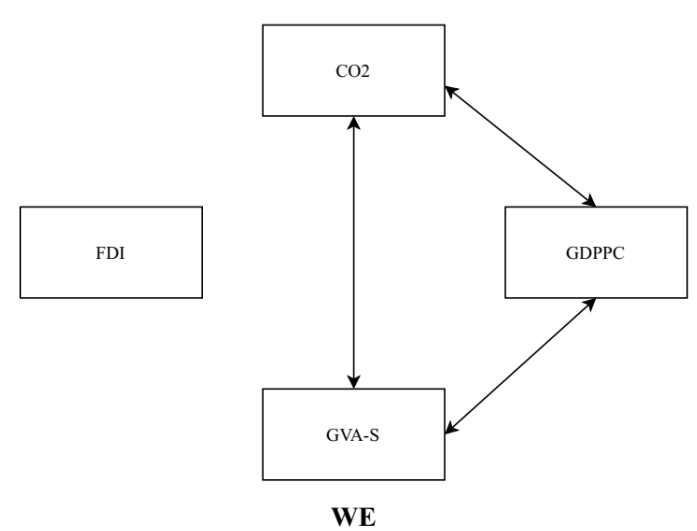


Figure 2, relation summary of MGVAand CGVA.

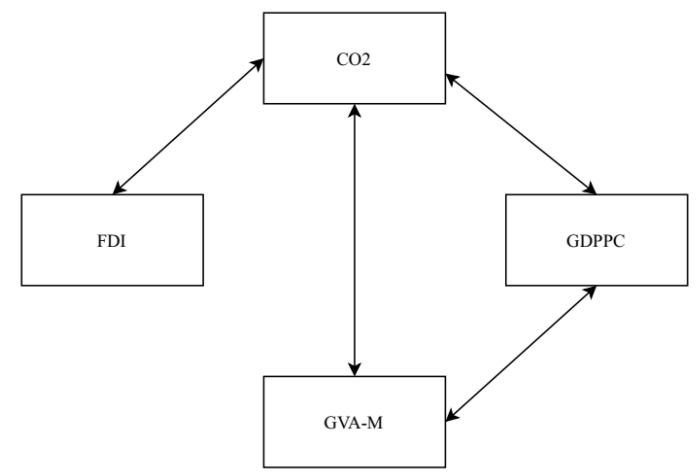

EE

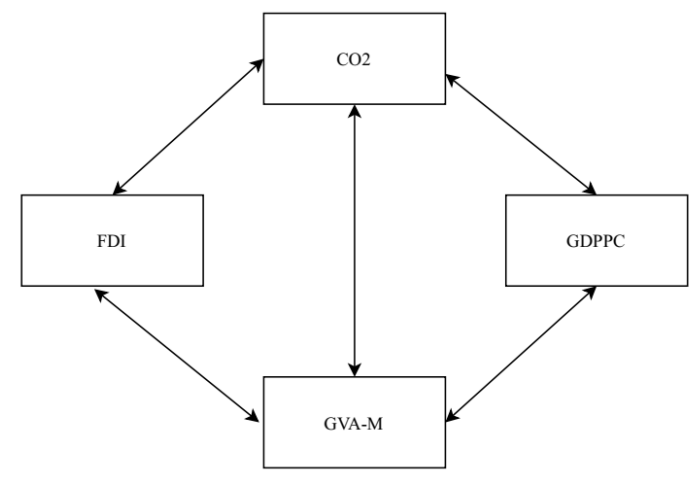

NE

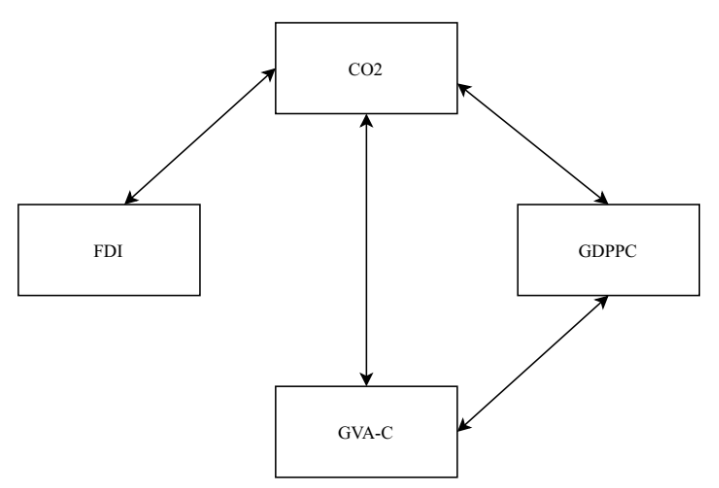

EE

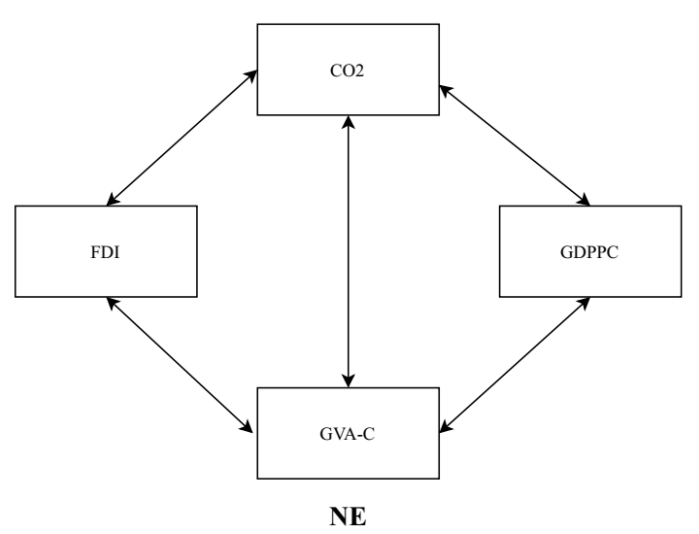

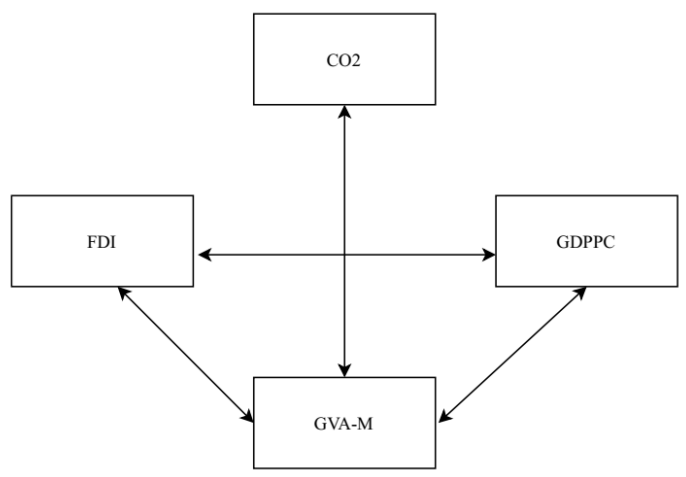

SE

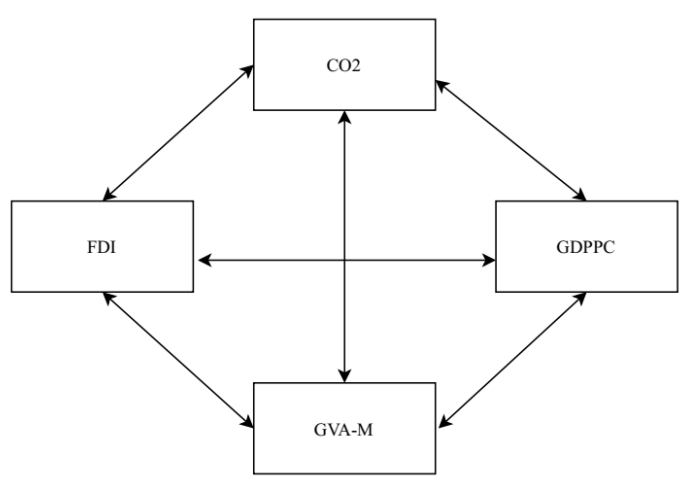

WE

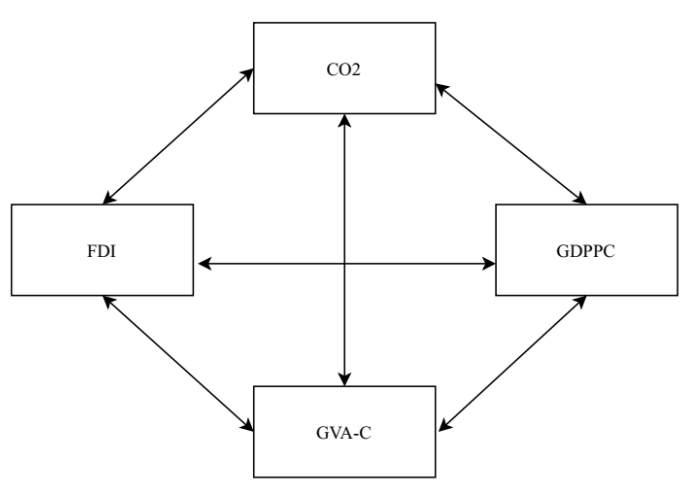

SE

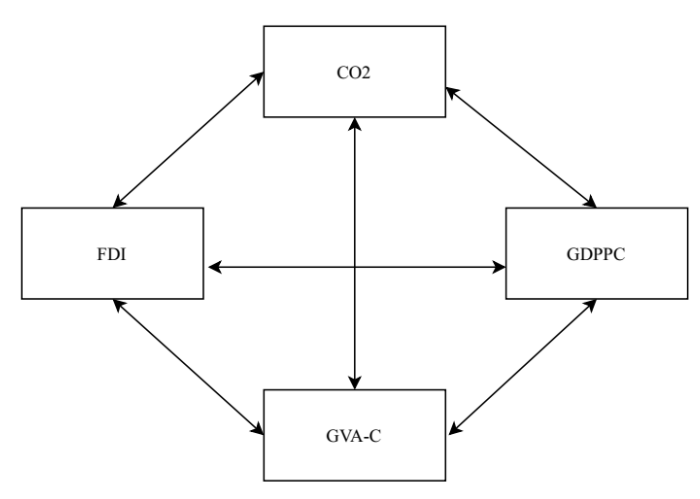

WE 
Table 1 summary of the literature review of $\mathrm{CO} 2$ emission and value added

\begin{tabular}{|c|c|c|c|c|}
\hline Author & Region & Methodology & Period & Scope \\
\hline (Zhang et al., 2019) & $\begin{array}{l}\text { Global/income } \\
\text { level } \\
\text { classification }\end{array}$ & $\begin{array}{l}\text { Environmental } \\
\text { Kuznets curve and } \\
\text { various }\end{array}$ & $1960-2014$ & $\begin{array}{l}\mathrm{CO} 2 \text { is directly related to income level, } \\
\text { higher-income higher EKC curve, } \\
\text { significant relation between manufacturing } \\
\text { and construction directly related to } \mathrm{CO} 2 \\
\text { emission }\end{array}$ \\
\hline (Jebli et al., 2020) & $\begin{array}{l}\text { Global/income } \\
\text { level } \\
\text { classification }\end{array}$ & $\begin{array}{l}\text { GMM and Granger } \\
\text { causality }\end{array}$ & $1990-2015$ & $\begin{array}{l}\text { Negative relation between } \mathrm{CO} 2 \text { emission } \\
\text { and, manufacturing and service sector } \\
\text { industries value-added in higher-income } \\
\text { countries, this relation is positive in low- } \\
\text { income industries }\end{array}$ \\
\hline (Asom \& Ijirshar, 2016) & Nigeria & $\begin{array}{l}\text { Augmented Dickey- } \\
\text { Fuller, Johansen co- } \\
\text { integration, unit root, } \\
\text { error correction }\end{array}$ & $1981-2015$ & $\begin{array}{l}\text { agriculture value-added have a positive and } \\
\text { insignificant effect on economic growth in } \\
\text { the short and long run }\end{array}$ \\
\hline (Rauf et al., 2018) & China & ARDL & $1968-2016$ & $\begin{array}{l}\text { Agriculture, services, and manufacturing } \\
\text { value-added have a significant and positive } \\
\text { relation with } \mathrm{CO} 2 \text { emission }\end{array}$ \\
\hline (Kołodziejczak, 2020) & Europe & Comparative analysis & $2000-2008$ & $\begin{array}{l}\text { Positive association between employment } \\
\text { and value added of different sectors }\end{array}$ \\
\hline (H. Liu \& Fan, 2017) & Multi country & Comparative analysis & $2000-2010$ & $\begin{array}{l}\text { Positive promotion of value-added based } \\
\text { accounting of } \mathrm{CO} 2\end{array}$ \\
\hline (Alam, 2015) & South Asia & $\begin{array}{l}\text { Environmental } \\
\text { Kuznets curve and } \\
\text { various }\end{array}$ & $1972-2010$ & $\begin{array}{l}\text { Negative and significant association } \\
\text { between agriculture value added and } \mathrm{CO} 2 \\
\text { emission, positive and significant } \\
\text { association between services sectors value } \\
\text { added and } \mathrm{CO} 2 \text { emission }\end{array}$ \\
\hline (Ceylan \& Özkan, 2013) & Europe & Comparative analysis & $\begin{array}{l}1995-2007 \\
\text { and } \\
2002-2007\end{array}$ & $\begin{array}{l}\text { positive relation between agriculture value } \\
\text { added and economic growth }\end{array}$ \\
\hline (Murshed et al., 2020) & OPEC & $\begin{array}{l}\text { Environmental } \\
\text { Kuznets curve and } \\
\text { various }\end{array}$ & $1992-2015$ & $\begin{array}{l}\text { Positive association between } \mathrm{CO} 2 \text { emission } \\
\text { and construction and services value added }\end{array}$ \\
\hline (Agboola \& Bekun, 2019) & Nigeria & $\begin{array}{l}\text { Environmental } \\
\text { Kuznets curve and } \\
\text { various }\end{array}$ & $1981-2014$ & $\begin{array}{l}\text { Positive association between } \mathrm{CO} 2 \text { emission } \\
\text { and FDI and agriculture value added }\end{array}$ \\
\hline (Prastiyo et al., 2020) & Indonesia & $\begin{array}{l}\text { Environmental } \\
\text { Kuznets curve and } \\
\text { various }\end{array}$ & $1970-2015$ & $\begin{array}{l}\text { Bidirectional causality between } \mathrm{CO} 2 \\
\text { emission and, manufacturing, agriculture } \\
\text { and urbanization }\end{array}$ \\
\hline (Samargandi, 2017) & Saudi Arabia & $\begin{array}{l}\text { Environmental } \\
\text { Kuznets curve, ARDL }\end{array}$ & $1970-2014$ & $\begin{array}{l}\text { Value addition in services and } \\
\text { manufacturing sectors positively causes } \\
\mathrm{CO} 2 \text { emission, technology and innovation } \\
\text { help to reduce } \mathrm{CO} 2 \text { emission with } \\
\text { enhancement of economic growth }\end{array}$ \\
\hline (Alamdarlo, 2016) & Iran & $\begin{array}{l}\text { Environmental } \\
\text { Kuznets curve and } \\
\text { various }\end{array}$ & $2001-2013$ & $\begin{array}{l}\text { Direct relation among water consumption, } \\
\text { agriculture value added and } \mathrm{CO} 2 \text { emission }\end{array}$ \\
\hline (Friesenbichler, 2016) & \begin{tabular}{|l|} 
Eastern Europe \\
and Central \\
Asia
\end{tabular} & $3 \mathrm{SLS}$ & $2010-2013$ & $\begin{array}{l}\text { Positive and direct association between } \\
\text { labor value added and innovation in } \\
\text { manufacturing and services industry }\end{array}$ \\
\hline
\end{tabular}

Source: author. 
Table 2 panel bifurcations

\begin{tabular}{|l|l|}
\hline \multicolumn{1}{|c|}{ Panel } & \multicolumn{1}{c|}{ Countries } \\
\hline Northern Europe & $\begin{array}{l}\text { Denmark, Finland, Ireland, Norway, } \\
\text { Sweden, United } \\
\text { Kingdom }\end{array}$ \\
\hline Southern Europe & Greece, Italy, Portugal, Slovenia, Spain, \\
\hline Western Europe & $\begin{array}{l}\text { Austria, Belgium, France, } \\
\text { Germany, Netherlands }\end{array}$ \\
\hline Eastern Europe & $\begin{array}{l}\text { Czech Republic, Hungary, Poland, } \\
\text { Romania, Ukraine }\end{array}$ \\
\hline
\end{tabular}

Source: author

Table-3, variable description

\begin{tabular}{|c|c|c|c|}
\hline Variable & Definition & $\begin{array}{c}\text { Unit of } \\
\text { measurement }\end{array}$ & Source \\
\hline $\mathrm{CO} 2$ emission & damage to the environment due to $\mathrm{CO} 2$ emission & $\begin{array}{l}\text { current US\$ } \\
\text { dollar in million }\end{array}$ & WDI \\
\hline $\begin{array}{l}\text { Foreign direct investment, } \\
\text { (FDI) }\end{array}$ & net inflows & $\begin{array}{l}\text { current US\$ in } \\
\text { million }\end{array}$ & WDI \\
\hline Economic growth (GDPPC) & GDP per capita & $\begin{array}{l}\text { current US\$ in } \\
\text { million }\end{array}$ & WDI \\
\hline Inflation (I) & consumer prices & annual \% & WDI \\
\hline Labor $(\mathrm{L})$ & labor force participation rate & $\begin{array}{l}\% \text { of total } \\
\text { population } \\
\text { ages } 15-64\end{array}$ & WDI \\
\hline Urbanization (U) & urban population growth & annual \% & WDI \\
\hline $\operatorname{Tax}(\mathrm{TA})$ & taxes on income, profits and capital gains & $\%$ of total taxes & WDI \\
\hline $\begin{array}{l}\text { Technology } \\
\text { (ICT) }\end{array}$ & Individuals using the Internet & $\%$ of population & WDI \\
\hline $\begin{array}{l}\text { Gross Value-Added } \\
\text { Agriculture sectors } \\
\text { (GVA-A) }\end{array}$ & $\begin{array}{l}\text { Representing the agriculture, industry, and services } \\
\text { sectors }\end{array}$ & $\begin{array}{l}\text { current US\$ in } \\
\text { million }\end{array}$ & WDI \\
\hline $\begin{array}{l}\text { Gross value added of Industry } \\
\text { involved in construction and } \\
\text { mining (CGVA) }\end{array}$ & $\begin{array}{l}\text { industry including construction, mining, electricity, } \\
\text { water, and gas (resource extractive industry) }\end{array}$ & $\begin{array}{l}\text { current US\$ in } \\
\text { million }\end{array}$ & WDI \\
\hline $\begin{array}{l}\text { Gross Value Added of } \\
\text { Manufacturing } \\
\text { (GVA-M) }\end{array}$ & manufacturing industries & $\begin{array}{l}\text { current US\$ in } \\
\text { million }\end{array}$ & WDI \\
\hline $\begin{array}{l}\text { Gros Value Added Service } \\
\text { sectors } \\
\text { (SGVA) }\end{array}$ & $\begin{array}{l}\text { industry including Wholesale, retail, trade transport, } \\
\text { government, financial, professional, and personal } \\
\text { services (education, health care real estate services, } \\
\text { hotels, and restaurants }\end{array}$ & $\begin{array}{l}\text { current US\$ in } \\
\text { million }\end{array}$ & WDI \\
\hline
\end{tabular}

Source: author 


\section{Table 4 descriptive statics}

\begin{tabular}{|c|c|c|c|c|c|c|c|c|c|c|c|c|c|c|c|c|c|}
\hline Variables & (1) & (2) & (3) & (4) & (5) & (6) & (7) & (8) & (9) & (10) & (11) & (12) & Obs & Mean & $\begin{array}{l}\text { Std. } \\
\text { Dev. }\end{array}$ & Min & Max \\
\hline (1) $\log \mathrm{CO} 2$ & 1.000 & & & & & & & & & & & & 399 & 7.834 & $\begin{array}{ll}4 & 1.03\end{array}$ & 5.341 & 10.145 \\
\hline (2) $\log$ FDI & $0.282 *$ & 1.000 & & & & & & & & & & & 399 & 6.937 & .063 & 6.459 & 7.458 \\
\hline (3) $\log$ GDPPC & -0.078 & $0.218^{*}$ & 1.000 & & & & & & & & & & 399 & 10.119 & .88 & 6.455 & 11.542 \\
\hline (4) $\log$ ICT & -0.006 & $0.149 *$ & $0.784 *$ & 1.000 & & & & & & & & & 399 & 3.952 & .712 & -.334 & 4.578 \\
\hline (5) log Inflation & -0.019 & $-0.107 *$ & $-0.627 *$ & $-0.608 *$ & 1.000 & & & & & & & & 399 & 2.526 & .238 & 1.709 & 4.072 \\
\hline (6) log Labor & $-0.136^{*}$ & $0.158^{*}$ & $0.616^{*}$ & $0.523 *$ & $-0.340 *$ & 1.000 & & & & & & & 399 & 4.268 & .078 & 4.084 & 4.421 \\
\hline (7) log Urban & $-0.152 *$ & $0.203^{*}$ & $0.658^{*}$ & $0.405^{*}$ & $-0.340 *$ & $0.439 *$ & 1.000 & & & & & & 399 & 1.714 & .13 & 1.11 & 2.107 \\
\hline (8) log Taxes & $0.218^{*}$ & $0.245^{*}$ & $0.434^{*}$ & $0.131^{*}$ & $-0.193 *$ & 0.031 & $0.353^{*}$ & 1.000 & & & & & 399 & 3.651 & .319 & 2.526 & 4.096 \\
\hline (9) $\log$ CGVA & $0.769 *$ & $0.350 *$ & $0.520^{*}$ & $0.404 *$ & $-0.353 *$ & $0.228^{*}$ & $0.261^{*}$ & $0.438^{*}$ & 1.000 & & & & 399 & 11.443 & 1.113 & 8.729 & 13.897 \\
\hline (10) $\log$ AGVA & $0.771 *$ & $0.360^{*}$ & $0.533^{*}$ & $0.420^{*}$ & $-0.376^{*}$ & $0.227 *$ & $0.282 *$ & $0.445^{*}$ & $0.985^{*}$ & 1.000 & & & 399 & 12.721 & 1.196 & 9.782 & 15.085 \\
\hline (11) $\log$ MGVA & $0.769 *$ & $0.356^{*}$ & $0.480^{*}$ & $0.386^{*}$ & $-0.363 *$ & $0.167 *$ & $0.205^{*}$ & $0.394 *$ & $0.972 *$ & $0.963 *$ & 1.000 & & 399 & 10.924 & 1.118 & 8.388 & 13.6 \\
\hline (12) $\log$ SGVA & $0.752 *$ & $0.365^{*}$ & $0.552 *$ & $0.434^{*}$ & $-0.398^{*}$ & $0.233^{*}$ & $0.302 *$ & $0.451 *$ & $0.972^{*}$ & $0.997 *$ & $0.953^{*}$ & 1.000 & 399 & 12.329 & 1.261 & 9.302 & 14.697 \\
\hline
\end{tabular}

\section{Table 5 results of panel unit root test}

\begin{tabular}{lll}
\hline & LLC test & \\
\hline Variables & t-stat & P value \\
$\log$ CO2 & $-3.019^{*}$ & 0.001 \\
$\log$ GDPPC & $-9.332^{*}$ & 0.000 \\
$\log$ FDI & $-3.478^{*}$ & 0.001 \\
$\log$ Labor & $-9.485^{*}$ & 0.000 \\
$\log$ Inflation & $-7.436^{*}$ & 0.000 \\
$\log$ Urban & $-5.845^{*}$ & 0.000 \\
$\log$ ITC & $-19.81^{*}$ & 0.000 \\
$\log$ Taxes & $-2.383^{*}$ & 0.009 \\
$\log$ CGVA & $-7.678^{*}$ & 0.000 \\
$\log$ AGVA & $-9.261^{*}$ & 0.000 \\
$\log$ MGVA & $-7.606^{*}$ & 0.000 \\
$\log$ SGVA & $-11.525^{*}$ & 0.000 \\
\hline Source: author, ${ }^{*},{ }^{*} p<0.05,{ }^{* *} p<0.01,{ }^{* * *} p<0.001$
\end{tabular}


Table 6, CGVA model equation summary statistics.

\begin{tabular}{|c|c|c|c|c|c|c|c|c|c|c|c|c|c|c|c|c|}
\hline & & Eastern & Europe & & & South & Europe & & & Norther & Europe & & & Western & Europe & \\
\hline & RMSE & $\mathrm{R} 2$ & Chai2 & $\mathrm{P}$ & RMSE & $\mathrm{R} 2$ & Chai2 & $\mathrm{P}$ & RMSE & $\mathrm{R} 2$ & Chai2 & $\mathrm{P}$ & RMSE & $\mathrm{R} 2$ & Chai2 & $\mathrm{P}$ \\
\hline $\log \mathrm{CO} 2$ & 0.26 & 0.87 & 1065.55 & 0.00 & .37 & 0.90 & 966.28 & 0.00 & .20 & 0.94 & 3469.51 & 0.00 & .29 & 0.89 & 1481.09 & 0.00 \\
\hline $\log F D I$ & .01 & 0.14 & 20.89 & 0.007 & .01 & 0.54 & 169.01 & 0.00 & .03 & 0.48 & 148.36 & 0.00 & .01 & 0.08 & 20.56 & 0.00 \\
\hline $\log G D P P C$ & .19 & 0.94 & 2271.38 & 0.00 & .14 & 0.77 & 382.60 & 0.00 & .14 & 0.80 & 545.69 & 0.00 & .10 & 0.82 & 458.35 & 0.00 \\
\hline logCGVA & 14326.93 & 0.87 & 1233.99 & 0.00 & 61966.14 & 0.86 & 764.76 & 0.00 & 35267.91 & 0.94 & 3544.61 & 0.00 & 89135.33 & 0.91 & 1631.04 & 0.00 \\
\hline
\end{tabular}

Source: author, ${ }^{*} p<0.05,{ }^{* *} p<0.01,{ }^{* * *} p<0.001$.

Table 7, AGVAmodel equation summary statistics.

\begin{tabular}{|c|c|c|c|c|c|c|c|c|c|c|c|c|c|c|c|c|}
\hline & & Eastern & Europe & & & South & Europe & & & Norther & Europe & & & Western & Europe & \\
\hline & RMSE & $\mathrm{R} 2$ & Chai2 & $\mathrm{P}$ & RMSE & $\mathrm{R} 2$ & Chai2 & $\mathrm{P}$ & RMSE & $\mathrm{R} 2$ & Chai2 & $\mathrm{P}$ & RMSE & $\mathrm{R} 2$ & Chai2 & $\mathrm{P}$ \\
\hline $\log \mathrm{CO} 2$ & .16 & 0.94 & 2811.73 & 0.00 & .12 & 0.90 & 12411.79 & 0.00 & .17 & 0.96 & 5084.60 & 0.00 & .18 & 0.95 & 4013.33 & 0.00 \\
\hline $\log F D I$ & .01 & 0.14 & 2811.73 & 0.003 & .01 & 0.52 & 12411.79 & 0.00 & .03 & 0.46 & 133.04 & 0.00 & .09 & 0.08 & 17.17 & 0.028 \\
\hline $\log \mathrm{GDPPC}$ & .14 & 0.97 & 3990.98 & 0.00 & .11 & 0.87 & 862.94 & 0.00 & .12 & 0.83 & 795.75 & 0.00 & .08 & 0.87 & 898.22 & 0.00 \\
\hline logGVA-A & .12 & 0.96 & 3991.38 & 0.00 & .11 & 0.90 & 17694.01 & 0.00 & .18 & 0.95 & 4694.05 & 0.00 & .17 & 0.96 & 4238.11 & 0.00 \\
\hline
\end{tabular}

Source: author, ${ }^{*} p<0.05,{ }^{* *} p<0.01,{ }^{* * *} p<0.001$.

Table 8, MGVAmodel equation summary statistics.

\begin{tabular}{|c|c|c|c|c|c|c|c|c|c|c|c|c|c|c|c|c|}
\hline & & Eastern & Europe & & & South & Europe & & & Norther & Europe & & & Western & Europe & \\
\hline & RMSE & $\mathrm{R} 2$ & Chai2 & $\mathrm{P}$ & RMSE & $\mathrm{R} 2$ & Chai2 & $\mathrm{P}$ & RMSE & R2 & Chai2 & $\mathrm{P}$ & RMSE & $\mathrm{R} 2$ & Chai2 & $\mathrm{P}$ \\
\hline $\log \mathrm{CO} 2$ & .22 & 0.90 & 1423.45 & 0.00 & .28 & 0.94 & 1783.85 & 0.00 & .32 & 0.87 & 1270.03 & 0.00 & .17 & 0.96 & 4639.56 & 0.00 \\
\hline $\operatorname{logFDI}$ & .01 & 0.14 & 21.38 & 0.006 & .01 & 0.55 & 148.29 & 0.00 & .03 & 0.51 & 159.07 & 0.00 & .10 & 0.07 & 33.99 & 0.00 \\
\hline $\log G D P P C$ & .14 & 0.97 & 4158.75 & 0.00 & .14 & 0.78 & 366.24 & 0.00 & .14 & 0.80 & 520.84 & 0.00 & .10 & 0.86 & 799.78 & 0.00 \\
\hline logMGVA & .15 & 0.95 & 2797.99 & 0.00 & .29 & 0.95 & 2315.99 & 0.00 & .27 & 0.87 & 1371.89 & 0.00 & .17 & 0.96 & 5252.78 & 0.00 \\
\hline
\end{tabular}

Source: author, ${ }^{*} p<0.05,{ }^{* *} p<0.01,{ }^{* * *} p<0.001$.

Table 9, SGVA model equation summary statistics.

\begin{tabular}{|c|c|c|c|c|c|c|c|c|c|c|c|c|c|c|c|c|}
\hline & \multirow[b]{2}{*}{ RMSE } & \multirow{2}{*}{$\begin{array}{l}\text { Eastern } \\
\mathrm{R} 2\end{array}$} & \multicolumn{2}{|l|}{ Europe } & \multicolumn{2}{|r|}{ South } & \multicolumn{2}{|l|}{ Europe } & \multicolumn{2}{|r|}{ Norther } & \multicolumn{2}{|l|}{ Europe } & \multicolumn{2}{|r|}{ Western } & \multicolumn{2}{|l|}{ Europe } \\
\hline & & & Chai2 & $\mathrm{P}$ & RMSE & R2 & Chai2 & $\mathrm{P}$ & RMSE & R2 & Chai2 & $\mathrm{P}$ & RMSE & $\mathrm{R} 2$ & Chai2 & $\mathrm{P}$ \\
\hline $\log \mathrm{CO} 2$ & .17 & 0.94 & 2492.16 & 0.00 & .12 & 0.95 & 11289.97 & 0.00 & .19 & 0.95 & 4102.69 & 0.00 & .19 & 0.95 & 3420.00 & 0.00 \\
\hline $\operatorname{logFDI}$ & .01 & 0.15 & 18.66 & 0.016 & .01 & 0.50 & 117.99 & 0.00 & .03 & 0.45 & 119.42 & 0.00 & .10 & 0.09 & 12.51 & 0.012 \\
\hline $\log G D P P C$ & .14 & 0.95 & 3869.97 & 0.00 & .11 & 0.87 & 867.99 & 0.00 & .13 & 0.81 & 628.47 & 0.00 & .08 & 0.87 & 849.71 & 0.00 \\
\hline $\operatorname{logSGVA}$ & .13 & 0.96 & 3884.47 & 0.00 & .12 & 0.95 & 15540.88 & 0.00 & .21 & 0.95 & 3843.10 & 0.00 & .19 & 0.95 & 3561.65 & 0.00 \\
\hline
\end{tabular}




\section{Table 10, result of 3SLS using GVA-A}

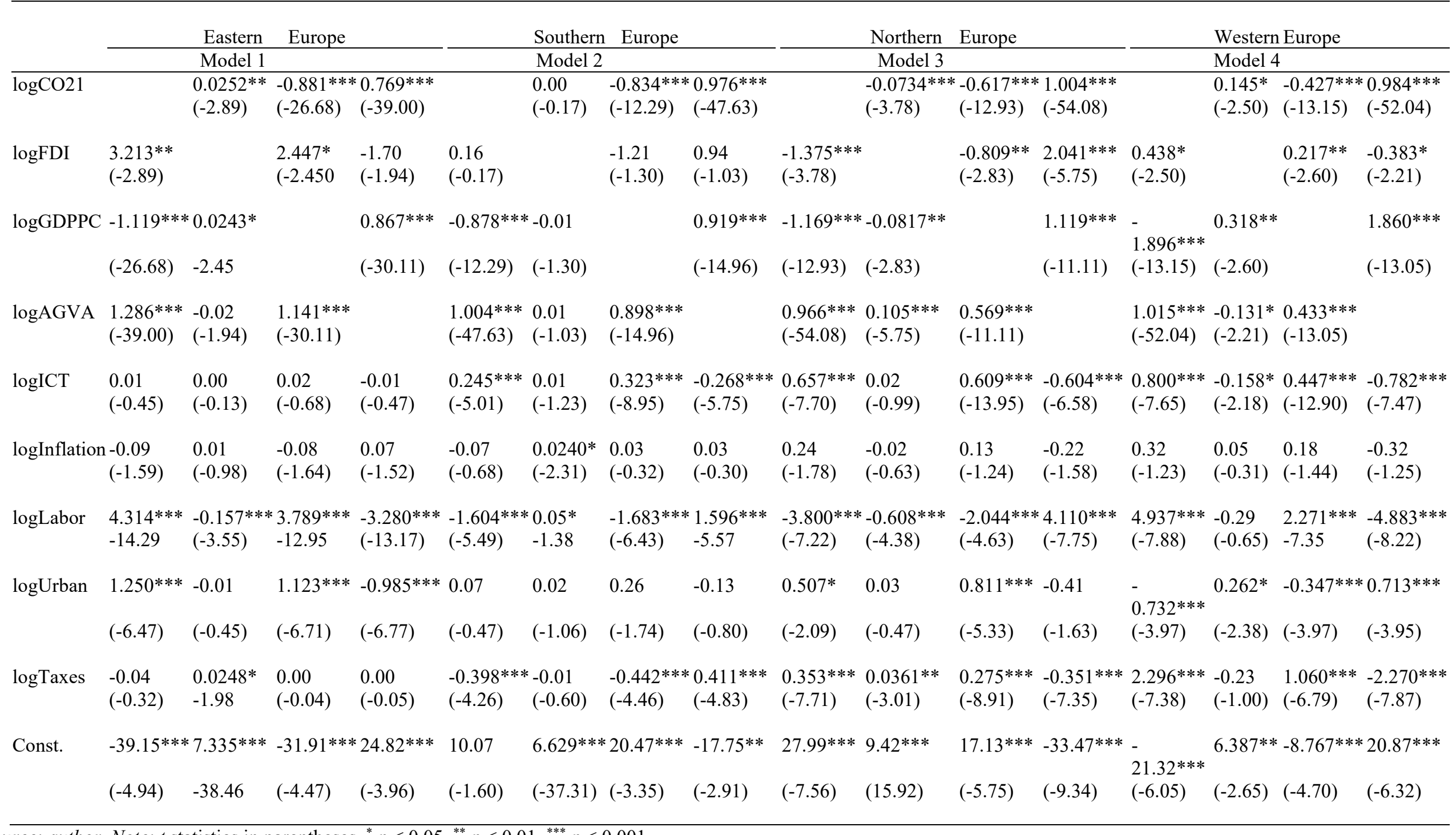

Source: author, Note: $t$ statistics in parentheses, ${ }^{*} p<0.05,{ }^{* *} p<0.01,{ }^{* * *} p<0.001$. 


\section{Table 11, result of 3SLS using SGVA}

\begin{tabular}{|c|c|c|c|c|c|c|c|c|c|c|c|c|c|c|c|c|}
\hline & & Eastern & Europe & & & Southern & Europe & & & Northern & Europe & & & Western & Europe & \\
\hline & & Model 1 & & & & Model 2 & & & & Model 3 & & & & Model 4 & & \\
\hline $\log \mathrm{CO} 21$ & & $\begin{array}{c}0.013 \\
(-1.55)\end{array}$ & $\begin{array}{c}-0.844^{* * *} \\
(-25.83)\end{array}$ & $\begin{array}{l}{ }^{*} 0.773^{* * *} \\
(-36.68)\end{array}$ & & $\begin{array}{l}0.04^{* * *} \\
(-4.21)\end{array}$ & $\begin{array}{c}-0.798^{* * *} \\
(-12.26)\end{array}$ & $\begin{array}{l}1.013^{* * *} \\
(-45.23)\end{array}$ & & $\begin{array}{c}-0.048^{* *} \\
(-2.64)\end{array}$ & $\begin{array}{c}-0.504^{* * *} \\
(-9.40)\end{array}$ & $\begin{array}{l}1.059^{* * *} \\
(-48.71)\end{array}$ & & $\begin{array}{l}0.073 \\
(-1.340)\end{array}$ & $\begin{array}{l}-0.397^{* * *} \\
(-12.50)\end{array}$ & $\begin{array}{l}\left(-004^{* * *}\right. \\
(-47.99)\end{array}$ \\
\hline $\log \mathrm{FDI}$ & $\begin{array}{c}1.848 \\
(-1.55)\end{array}$ & & $\begin{array}{c}1.129 \\
(-1.11)\end{array}$ & $\begin{array}{l}-0.483 \\
(-0.52)\end{array}$ & $\begin{array}{c}4.010^{* * *} \\
(-4.21)\end{array}$ & & $\begin{array}{c}1.787 \\
(-1.90)\end{array}$ & $\begin{array}{c}-3.010^{* *} \\
(-3.00)\end{array}$ & $\begin{array}{c}-1.059^{* *} \\
(-2.64)\end{array}$ & & $\begin{array}{l}-0.439 \\
(-1.41)\end{array}$ & $\begin{array}{c}1.999^{* * *} \\
(-4.78)\end{array}$ & $\begin{array}{c}0.255 \\
9-1.34)\end{array}$ & & $\begin{array}{c}0.146 \\
(-1.710)\end{array}$ & $\begin{array}{l}-0.193 \\
(-1.01)\end{array}$ \\
\hline $\log \mathrm{GDPPC}$ & $\begin{array}{l}-1.164^{* * *} \\
(-25.83)\end{array}$ & $\begin{array}{r}0.011 \\
(-1.11)\end{array}$ & & $\begin{array}{l}0.908^{* * *} \\
(-29.61)\end{array}$ & $\begin{array}{l}-0.928^{* * *} \\
(-12.26)\end{array}$ & $\begin{array}{r}0.021 \\
(-1.90)\end{array}$ & & $\begin{array}{l}1.009^{* * *} \\
-15.050\end{array}$ & $\begin{array}{l}-0.991^{\text {*** }} \\
(-9.40)\end{array}$ & $\begin{array}{c}-0.039 \\
(-1.41)\end{array}$ & & $\begin{array}{l}0.938^{* * *} \\
(-7.65)\end{array}$ & $\begin{array}{l}-1.969^{* * *} \\
(-12.50)\end{array}$ & $\begin{array}{r}0.207 \\
(-1.71)\end{array}$ & & $\begin{array}{l}1.972^{* * *} \\
(-12.41)\end{array}$ \\
\hline $\operatorname{logSGVA}$ & $\begin{array}{l}1.276^{* * *} \\
(-36.68)\end{array}$ & $\begin{array}{c}-0.006 \\
(-0.52)\end{array}$ & $\begin{array}{l}1.087^{* * *} \\
(-29.61)\end{array}$ & & $\begin{array}{l}0.967^{* * *} \\
(-45.23)\end{array}$ & $\begin{array}{l}-0.029^{* *} \\
(-3.00)\end{array}$ & $\begin{array}{l}0.828^{* * *} \\
(-15.05)\end{array}$ & & $\begin{array}{l}0.906^{* * *} \\
(-48.71)\end{array}$ & $\begin{array}{l}0.0770^{* * *} \\
9-4.78)\end{array}$ & $\begin{array}{l}{ }^{*} 0.408^{* * *} \\
(-7.65)\end{array}$ & & $\begin{array}{l}0.994^{* * *} \\
(-47.99)\end{array}$ & $\begin{array}{c}-0.055 \\
(-1.01)\end{array}$ & $\begin{array}{l}0.393^{* * *} \\
(-12.41)\end{array}$ & \\
\hline $\log \mathrm{ICT}$ & $\begin{array}{r}0.031 \\
(-0.98)\end{array}$ & $\begin{array}{c}-0.001 \\
(-0.20)\end{array}$ & $\begin{array}{r}0.033 \\
(-1.27)\end{array}$ & $\begin{array}{c}-0.025 \\
(-1.02)\end{array}$ & $\begin{array}{l}0.297^{* * *} \\
-5.760\end{array}$ & $\begin{array}{c}-0.003 \\
(-0.52)\end{array}$ & $\begin{array}{c}0.357^{* * *} \\
-10.190\end{array}$ & $\begin{array}{l}-0.334^{* * *} \\
(-6.57)\end{array}$ & $\begin{array}{l}0.556^{* * *} \\
(-5.74)\end{array}$ & $\begin{array}{l}-0.002 \\
(-0.08)\end{array}$ & $\begin{array}{l}0.647^{* * *} \\
(-13.76)\end{array}$ & $\begin{array}{l}-0.487^{* * *} \\
(-4.45)\end{array}$ & $\begin{array}{l}0.811^{* * *} \\
(-7.13)\end{array}$ & $\begin{array}{l}-0.115 \\
(-1.59)\end{array}$ & $\begin{array}{c}0.442^{* * *} \\
(-12.43)\end{array}$ & $\begin{array}{l}-0.808^{* * *} \\
(-6.96)\end{array}$ \\
\hline logInflation & $\begin{array}{c}-0.030 \\
(-0.50)\end{array}$ & $\begin{array}{r}0.004 \\
(-0.80)\end{array}$ & $\begin{array}{c}-0.027 \\
(-0.53)\end{array}$ & $\begin{array}{r}0.019 \\
(-0.42)\end{array}$ & $\begin{array}{r}0.031 \\
(-0.29)\end{array}$ & $\begin{array}{l}0.0211^{*} \\
(-2.03)\end{array}$ & $\begin{array}{r}0.121 \\
(-1.25)\end{array}$ & $\begin{array}{c}-0.071 \\
(-0.66)\end{array}$ & $\begin{array}{c}0.307^{*} \\
(-2.04)\end{array}$ & $\begin{array}{c}-0.024 \\
(-0.74)\end{array}$ & $\begin{array}{c}0.110 \\
(-1.00)\end{array}$ & $\begin{array}{c}-0.300 \\
(-1.83)\end{array}$ & $\begin{array}{r}0.457 \\
(-1.63)\end{array}$ & $\begin{array}{r}0.064 \\
(-0.42)\end{array}$ & $\begin{array}{c}0.228 \\
(-1.82)\end{array}$ & $\begin{array}{c}-0.468 \\
(-1.67)\end{array}$ \\
\hline logLabor & $\begin{array}{l}4.914^{* * *} \\
-15.380\end{array}$ & $\begin{array}{l}-0.109^{*} \\
(-2.31)\end{array}$ & $\begin{array}{l}4.140^{* * *} \\
-13.780\end{array}$ & $\begin{array}{l}-3.76^{* * *} \\
(-14.17)\end{array}$ & $\begin{array}{l}-2.179^{* * *} \\
(-7.09)\end{array}$ & $\begin{array}{l}0.112^{* *} \\
(-3.27)\end{array}$ & $\begin{array}{l}-2.092^{* * *} \\
(-7.98)\end{array}$ & $\begin{array}{l}2.259^{* * *} \\
(-7.23)\end{array}$ & $\begin{array}{l}-3.884^{* * *} \\
(-6.69)\end{array}$ & $\begin{array}{l}{ }^{*}-0.538^{* * *} \\
(-3.87)\end{array}$ & $\begin{array}{l}{ }^{*}-1.407^{* *} \\
(-2.92)\end{array}$ & $\begin{array}{l}4.546^{* * *} \\
(-7.34)\end{array}$ & $\begin{array}{l}5.383^{* * *} \\
(-7.92)\end{array}$ & $\begin{array}{r}0.049 \\
(-0.11)\end{array}$ & $\begin{array}{l}2.320^{* * *} \\
(-7.27)\end{array}$ & $\begin{array}{l}{ }^{*}-5.445^{* * *} \\
(-8.30)\end{array}$ \\
\hline logUrban & $\begin{array}{l}0.830^{* * *} \\
(-4.11)\end{array}$ & $\begin{array}{r}0.009 \\
(-0.52)\end{array}$ & $\begin{array}{l}0.723^{* * *} \\
(-4.29)\end{array}$ & $\begin{array}{l}-0.67^{* * *} \\
(-4.30)\end{array}$ & $\begin{array}{c}0.337^{*} \\
(-2.01)\end{array}$ & $\begin{array}{r}0.007 \\
(-0.40)\end{array}$ & $\begin{array}{l}0.479^{* *} \\
(-3.25)\end{array}$ & $\begin{array}{l}-0.403^{*} \\
(-2.38)\end{array}$ & $\begin{array}{r}0.501 \\
(-1.83)\end{array}$ & $\begin{array}{c}0.019 \\
(-0.30)\end{array}$ & $\begin{array}{l}1.131^{* * *} \\
(-7.17)\end{array}$ & $\begin{array}{c}-0.343 \\
(-1.14)\end{array}$ & $\begin{array}{l}-0.940^{* * *} \\
(-4.70)\end{array}$ & $\begin{array}{c}*^{*} 0.229^{*} \\
(-2.01)\end{array}$ & $\begin{array}{l}-0.415^{* * *} \\
(-4.57)\end{array}$ & $\begin{array}{l}0.935^{* * *} \\
(-4.69)\end{array}$ \\
\hline logTaxes & $\begin{array}{c}0.146 \\
(-1.10)\end{array}$ & $\begin{array}{r}0.025 \\
(-1.95)\end{array}$ & $\begin{array}{r}0.161 \\
(-1.43)\end{array}$ & $\begin{array}{c}-0.148 \\
(-1.44)\end{array}$ & $\begin{array}{l}-0.484^{* * *} \\
(-4.91)\end{array}$ & $\begin{array}{r}0.015 \\
(-1.17)\end{array}$ & $\begin{array}{l}-0.483^{* * *} \\
(-4.87)\end{array}$ & $\begin{array}{l}0.514^{* * *} \\
(-5.54)\end{array}$ & $\begin{array}{l}0.335^{* * *} \\
(-6.58)\end{array}$ & $\begin{array}{l}0.0267^{*} \\
(-2.25)\end{array}$ & $\begin{array}{l}0.270^{* * *} \\
(-8.04)\end{array}$ & $\begin{array}{l}-0.343^{* * *} \\
(-6.10)\end{array}$ & $\begin{array}{l}2.181^{* * *} \\
(-6.51)\end{array}$ & $\begin{array}{c}-0.050 \\
(-0.23)\end{array}$ & $\begin{array}{l}0.958^{* * *} \\
(-6.08)\end{array}$ & $\begin{array}{l}{ }^{*}-2.206^{* * *} \\
(-6.93)\end{array}$ \\
\hline Const. & $\begin{array}{l}-31.25^{* * *} \\
(-3.70)\end{array}$ & $\begin{array}{l}{ }^{*} 7.128^{* * *} \\
(-36.15)\end{array}$ & $\begin{array}{l}-23.50^{* *} \\
(-3.23)\end{array}$ & $\begin{array}{l}17.70^{* *} \\
(-2.65)\end{array}$ & $\begin{array}{l}-13.41^{*} \\
(-2.10)\end{array}$ & $\begin{array}{l}6.178^{* * *} \\
(-33.96)\end{array}$ & $\begin{array}{r}1.779 \\
(-0.29)\end{array}$ & $\begin{array}{r}5.892 \\
(-0.88)\end{array}$ & $\begin{array}{l}25.72^{* * *} \\
(-6.30)\end{array}$ & $\begin{array}{l}9.023^{* * *} \\
(-15.36)\end{array}$ & $\begin{array}{l}12.50^{* * *} \\
(-3.86)\end{array}$ & $\begin{array}{l}-34.37^{* * *} \\
(-8.17)\end{array}$ & $\begin{array}{l}-20.15^{* * *} \\
(-5.30)\end{array}$ & $\begin{array}{c}* 4.797^{*} \\
(-2.02)\end{array}$ & $\begin{array}{l}-7.678^{* * *} \\
(-4.07)\end{array}$ & $\begin{array}{l}20.13^{* * *} \\
(-5.51)\end{array}$ \\
\hline
\end{tabular}

Source: author, Note:t statistics in parentheses, ${ }^{*} p<0.05,{ }^{* *} p<0.01,{ }^{* * *} p<0.001$. 


\section{Table 12, result of 3SLS using GVA-M}

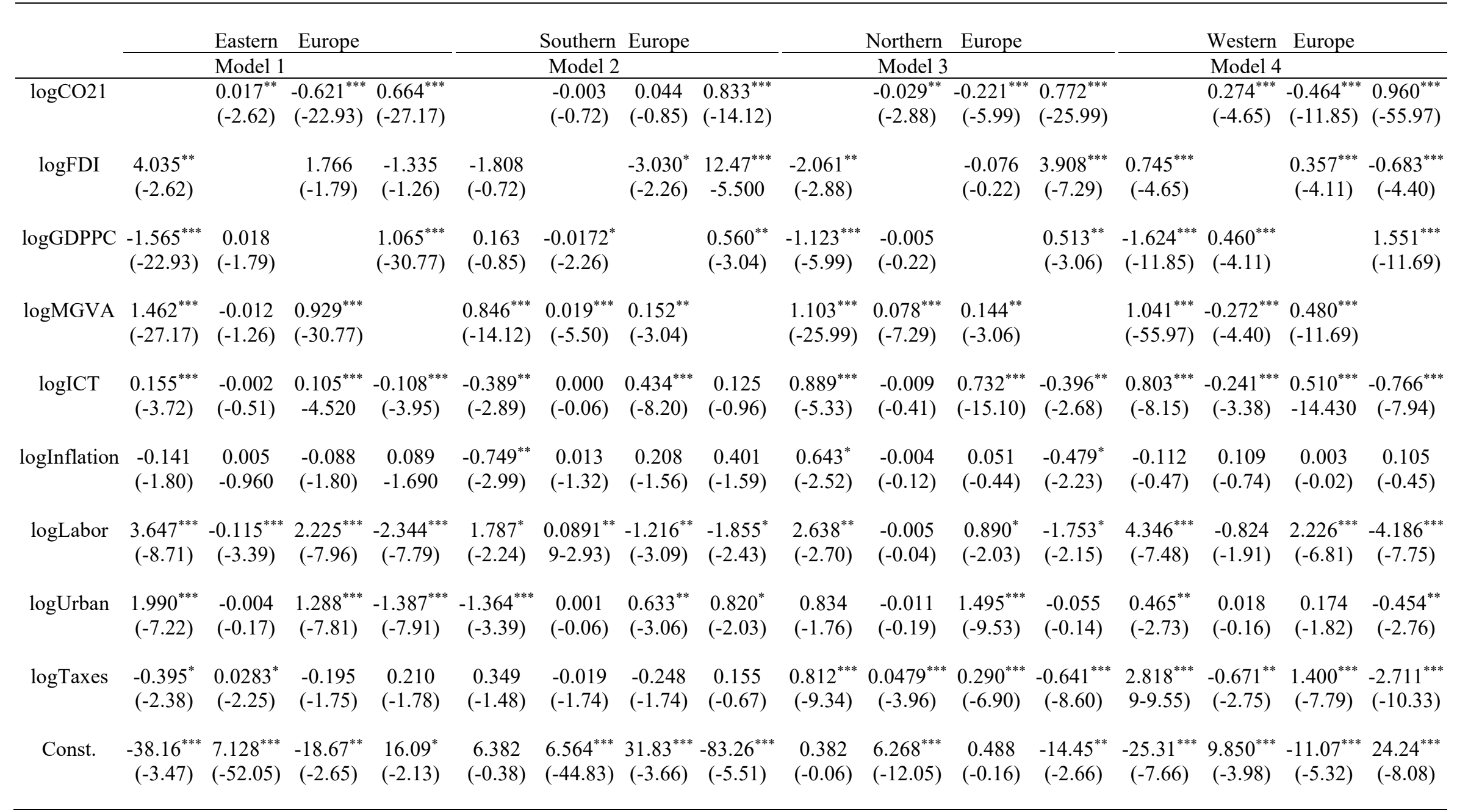

Source: author, Note:t statistics in parentheses, ${ }^{*} p<0.05,{ }^{* *} p<0.01,{ }^{* * *} p<0.001$. 


\section{Table 13, result of 3SLS using CGVA}

\begin{tabular}{|c|c|c|c|c|c|c|c|c|c|c|c|c|c|c|c|c|}
\hline \multirow{3}{*}{$\overline{\log C O} 21$} & & \multirow{2}{*}{$\begin{array}{l}\text { Eastern } \\
\text { Model 1 }\end{array}$} & \multicolumn{3}{|l|}{ Europe } & \multirow{2}{*}{$\begin{array}{l}\text { South } \\
\text { Model } 2 \\
\end{array}$} & \multicolumn{3}{|l|}{ Europe } & \multirow{2}{*}{$\frac{\text { Norther }}{\text { Model } 3}$} & \multicolumn{3}{|l|}{ Europe } & \multirow{2}{*}{$\frac{\text { West }}{\text { Model } 4}$} & \multicolumn{2}{|l|}{ Europe } \\
\hline & & & & & & & & & & & & & & & & \\
\hline & & $\begin{array}{l}0.0136^{*} \\
(-2.45)\end{array}$ & $\begin{array}{l}-0.712 * * * \\
(-17.93)\end{array}$ & $\begin{array}{l}53586.2 * * * \\
(-23.05)\end{array}$ & & $\begin{array}{l}0.009^{* *} \\
(-3.08)\end{array}$ & $\begin{array}{l}0.147 * * * \\
(-3.90)\end{array}$ & $\begin{array}{l}68769.6^{* * *} \\
(-4.76)\end{array}$ & & $\begin{array}{l}-0.067^{* * *} \\
(-4.21)\end{array}$ & $\begin{array}{l}-0.377^{* * *} \\
(-6.62)\end{array}$ & $\begin{array}{l}167989.5^{* * * *} \\
(-45.10)\end{array}$ & & $\begin{array}{l}0.109^{* *} \\
(-3.04)\end{array}$ & $\begin{array}{l}-0.0976^{* * *} \\
(-2.59)\end{array}$ & $\begin{array}{l}* 313218.7 * * * \\
(-31.37)\end{array}$ \\
\hline $\operatorname{logFDI}$ & $\begin{array}{l}4.339^{*} \\
(-2.45)\end{array}$ & & $\begin{array}{l}2.12 \\
(-1.60)\end{array}$ & $\begin{array}{l}-83088.90 \\
(-0.84)\end{array}$ & $\begin{array}{l}10.04 * * \\
(-3.08)\end{array}$ & & $\begin{array}{l}-3.833^{* *} \\
(-2.85)\end{array}$ & $\begin{array}{l}2884903.8^{* * *} \\
(-5.90)\end{array}$ & $\begin{array}{l}-1.836^{* * *} \\
(-4.21)\end{array}$ & & $\begin{array}{l}-0.36 \\
(-1.07)\end{array}$ & $\begin{array}{l}472725.8^{* * *} \\
(-6.73)\end{array}$ & $\begin{array}{l}0.851^{* *} \\
(-3.04)\end{array}$ & & $\begin{array}{l}0.219^{*} \\
(-2.06)\end{array}$ & $\begin{array}{l}-229945.7 * * \\
(-2.59)\end{array}$ \\
\hline $\log \mathrm{GDPPC}$ & $\begin{array}{l}-1.314 * * * \\
(-17.93)\end{array}$ & $\begin{array}{l}0.01 \\
(-1.60)\end{array}$ & & $\begin{array}{l}73106.5^{* * *} \\
(-21.77)\end{array}$ & $\begin{array}{l}0.954 * * * \\
(-3.90)\end{array}$ & $\begin{array}{l}-0.022 * * \\
(-2.85)\end{array}$ & & $\begin{array}{l}135107.6^{* * *} \\
(-3.40)\end{array}$ & $\begin{array}{l}-0.783^{* * *} \\
(-6.62)\end{array}$ & $\begin{array}{l}-0.03 \\
(-1.07)\end{array}$ & & $\begin{array}{l}104020.4^{* * * *} \\
(-4.84)\end{array}$ & $\begin{array}{l}-0.698^{* *} \\
(-2.59)\end{array}$ & $\begin{array}{l}0.200^{*} \\
(-2.06)\end{array}$ & & $\begin{array}{l}182512.4^{*} \\
(-2.14)\end{array}$ \\
\hline $\log \mathrm{CGVA}$ & $\begin{array}{l}1.78 \mathrm{e}-5^{* * *} \\
(-23.05)\end{array}$ & $\begin{array}{l}*-8.67 \mathrm{e}-8 \\
(-0.84)\end{array}$ & $\begin{array}{l}1.32 \mathrm{e}-5^{* * *} \\
(-21.77)\end{array}$ & & $\begin{array}{l}2.65 \mathrm{e}-6^{* * * *} \\
(-4.76)\end{array}$ & $\begin{array}{l}9.69 \mathrm{e}-8^{* * *} \\
(-5.90)\end{array}$ & $\begin{array}{l}* 8.03 \mathrm{e}-7 * * * \\
(-3.40)\end{array}$ & & $\begin{array}{l}5.65 \mathrm{e}-6^{* * *} \\
(-45.10)\end{array}$ & $\begin{array}{l}* 5.83 \mathrm{e}-7 * * * \\
(-6.73)\end{array}$ & $\begin{array}{l}* 1.68 \mathrm{e}-6^{* * *} \\
(-4.84)\end{array}$ & & $\begin{array}{l}3.15 \mathrm{e}-6^{* * *} \\
(-31.37)\end{array}$ & $\begin{array}{l}*-2.96 \mathrm{e}-7 * \\
(-2.59)\end{array}$ & $\begin{array}{l}* 2.57 \mathrm{e}-7 * \\
-2.14\end{array}$ & \\
\hline $\log \mathrm{ICT}$ & $\begin{array}{l}0.322 * * * \\
(-6.51)\end{array}$ & $\begin{array}{l}0.00 \\
(-0.62)\end{array}$ & $\begin{array}{l}0.259 * * * \\
(-9.29)\end{array}$ & $\begin{array}{l}-18298.1 * * * \\
(-7.04)\end{array}$ & $\begin{array}{l}-0.580 * * \\
(-3.22)\end{array}$ & $\begin{array}{l}0.00 \\
(-0.39)\end{array}$ & $\begin{array}{l}0.387 * * * \\
(-6.93)\end{array}$ & $\begin{array}{l}46777.90 \\
(-1.67)\end{array}$ & $\begin{array}{l}0.687 * * * \\
(-6.55)\end{array}$ & $\begin{array}{l}0.02 \\
(-0.72)\end{array}$ & $\begin{array}{l}0.756^{* * *} \\
(-15.72)\end{array}$ & $\begin{array}{l}-93784.8 * * * \\
(-4.94)\end{array}$ & $\begin{array}{l}0.34 \\
(-1.80)\end{array}$ & $\begin{array}{l}-0.12 \\
(-1.75)\end{array}$ & $\begin{array}{l}0.557 * * * \\
(-13.03)\end{array}$ & $\begin{array}{l}-81584.40 \\
(-1.38)\end{array}$ \\
\hline logInflation & $\begin{array}{l}1-0.288^{* *} \\
(-3.23)\end{array}$ & $\begin{array}{l}0.01 \\
(-1.05)\end{array}$ & $\begin{array}{l}-0.218^{* * *} \\
(-3.39)\end{array}$ & $\begin{array}{l}15287.6^{* *} \\
(-3.10)\end{array}$ & $\begin{array}{l}-1.278^{* * *} \\
(-3.81)\end{array}$ & $\begin{array}{l}0.01 \\
(-0.85)\end{array}$ & $\begin{array}{l}0.18 \\
(-1.31)\end{array}$ & $\begin{array}{l}131934.3^{*} \\
(-2.43)\end{array}$ & $\begin{array}{l}-0.10 \\
(-0.60)\end{array}$ & $\begin{array}{l}-0.06 \\
(-1.80)\end{array}$ & $\begin{array}{l}-0.06 \\
(-0.53)\end{array}$ & $\begin{array}{l}24068.60 \\
(-0.86)\end{array}$ & $\begin{array}{l}-0.904 * \\
(-2.19)\end{array}$ & $\begin{array}{l}0.15 \\
(-1.01)\end{array}$ & $\begin{array}{l}0.11 \\
(-0.68)\end{array}$ & $\begin{array}{l}284546.0^{*} \\
(-2.17)\end{array}$ \\
\hline logLabor & $\begin{array}{l}4.065^{* * *} \\
(-8.48)\end{array}$ & $\begin{array}{l}-0.108^{* *} \\
(-3.21)\end{array}$ & $\begin{array}{l}2.869 * * * \\
(-7.57)\end{array}$ & $\begin{array}{l}-209956.1 * * * \\
(-7.46)\end{array}$ & $\begin{array}{l}2.08 \\
(-1.78)\end{array}$ & $\begin{array}{l}0.137 * * * * \\
(-4.19)\end{array}$ & $\begin{array}{l}-0.64 \\
(-1.44)\end{array}$ & $\begin{array}{l}-858836.3 * * * \\
(-5.26)\end{array}$ & $\begin{array}{l}-2.481 * * * \\
(-4.02)\end{array}$ & $\begin{array}{l}-0.442 * * * \\
(-3.64)\end{array}$ & $\begin{array}{l}-0.24 \\
(-0.52)\end{array}$ & $\begin{array}{l}487580.1 * * * \\
(-4.61)\end{array}$ & $\begin{array}{l}1.13 \\
(-1.15)\end{array}$ & $\begin{array}{l}0.16 \\
(-0.46)\end{array}$ & $\begin{array}{l}0.838^{*} \\
(-2.29)\end{array}$ & $\begin{array}{l}-359382.70 \\
(-1.17)\end{array}$ \\
\hline logUrban & $\begin{array}{l}1.762^{* * *} \\
(-5.63)\end{array}$ & $\begin{array}{l}0.00 \\
(-0.22)\end{array}$ & $\begin{array}{l}1.354^{* * *} \\
(-6.10)\end{array}$ & $\begin{array}{l}-101952.7 * * * \\
(-6.24)\end{array}$ & $\begin{array}{l}-1.926^{* * *} \\
(-3.61)\end{array}$ & $\begin{array}{l}0.00 \\
(-0.14)\end{array}$ & $\begin{array}{l}0.620^{* *} \\
(-2.98)\end{array}$ & $\begin{array}{l}172378.0^{*} \\
(-1.99)\end{array}$ & $\begin{array}{l}0.29 \\
(-0.96)\end{array}$ & $\begin{array}{l}-0.01 \\
(-0.20)\end{array}$ & $\begin{array}{l}1.333^{* * *} \\
(-8.25)\end{array}$ & $\begin{array}{l}-2263.70 \\
(-0.04)\end{array}$ & $\begin{array}{l}1.805^{* * *} \\
(-6.06)\end{array}$ & $\begin{array}{l}0.00 \\
(-0.04)\end{array}$ & $\begin{array}{l}-0.02 \\
(-0.13)\end{array}$ & $\begin{array}{l}-582411.1 * * * \\
(-6.26)\end{array}$ \\
\hline logTaxes & $\begin{array}{l}0.02 \\
(-0.12)\end{array}$ & $\begin{array}{l}0.0256^{*} \\
(-2.02)\end{array}$ & $\begin{array}{l}0.14 \\
(-0.95)\end{array}$ & $\begin{array}{l}-9035.30 \\
(-0.82)\end{array}$ & $\begin{array}{l}1.834 * * * \\
(-7.19)\end{array}$ & $\begin{array}{l}-0.0217^{*} \\
(-2.13)\end{array}$ & $\begin{array}{l}-0.316^{*} \\
(-2.34)\end{array}$ & $\begin{array}{l}-23326.80 \\
(-0.43)\end{array}$ & $\begin{array}{l}0.08 \\
(-1.52)\end{array}$ & $\begin{array}{l}0.00 \\
(-0.37)\end{array}$ & $\begin{array}{l}0.189^{* * *} \\
(-5.43)\end{array}$ & $\begin{array}{l}-8733.60 \\
(-0.90)\end{array}$ & $\begin{array}{l}1.205^{*} \\
(-2.45)\end{array}$ & $\begin{array}{l}-0.08 \\
(-0.41)\end{array}$ & $\begin{array}{l}0.425^{*} \\
(-2.16)\end{array}$ & $\begin{array}{l}-389160.6^{* *} \\
(-2.59)\end{array}$ \\
\hline Const. & $\begin{array}{l}-31.53 * \\
(-2.49)\end{array}$ & $\begin{array}{l}7.052^{* * *} \\
(-58.68)\end{array}$ & $\begin{array}{l}*-15.70 \\
(-1.66)\end{array}$ & $\begin{array}{l}643763.40 \\
(-0.91)\end{array}$ & $\begin{array}{l}-78.54 * * * \\
(-3.68)\end{array}$ & $\begin{array}{l}6.538 * * * \\
(-44.77)\end{array}$ & $\begin{array}{l}36.20 * * * \\
(-4.17)\end{array}$ & $\begin{array}{l}-18777466.8^{* * *} \\
(-5.76)\end{array}$ & $\begin{array}{l}34.90 * * * \\
(-7.86)\end{array}$ & $\begin{array}{l}9.629 * * * \\
(-16.70)\end{array}$ & $\begin{array}{l}10.64 * * \\
(-2.93)\end{array}$ & $\begin{array}{l}-7218971.5^{* * *} \\
(-10.15)\end{array}$ & $\begin{array}{l}*-2.95 \\
(-0.54)\end{array}$ & $\begin{array}{l}3.74 \\
(-1.86)\end{array}$ & $\begin{array}{l}1.99 \\
(-0.94)\end{array}$ & $\begin{array}{l}1055879.80 \\
(-0.62)\end{array}$ \\
\hline
\end{tabular}


Figures

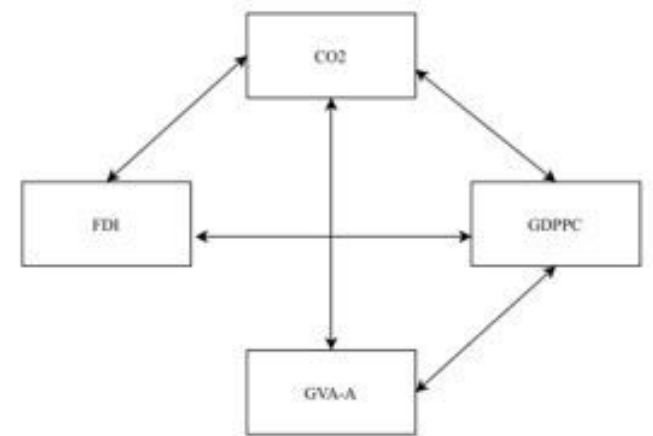

EE
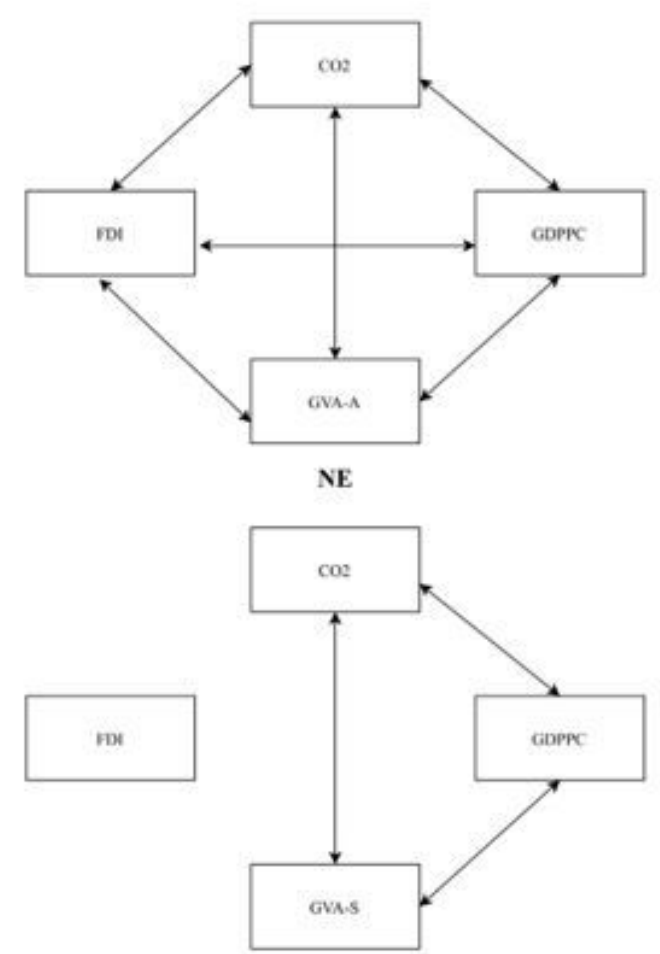

EE

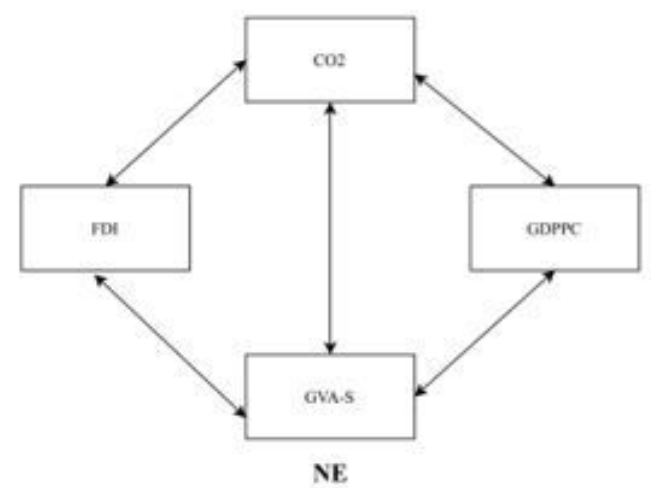

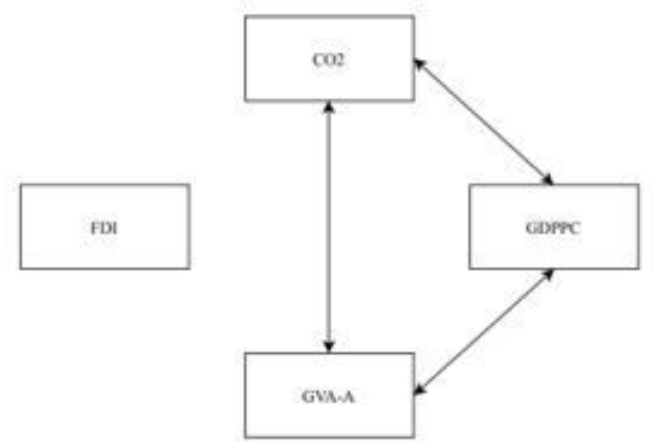

SE
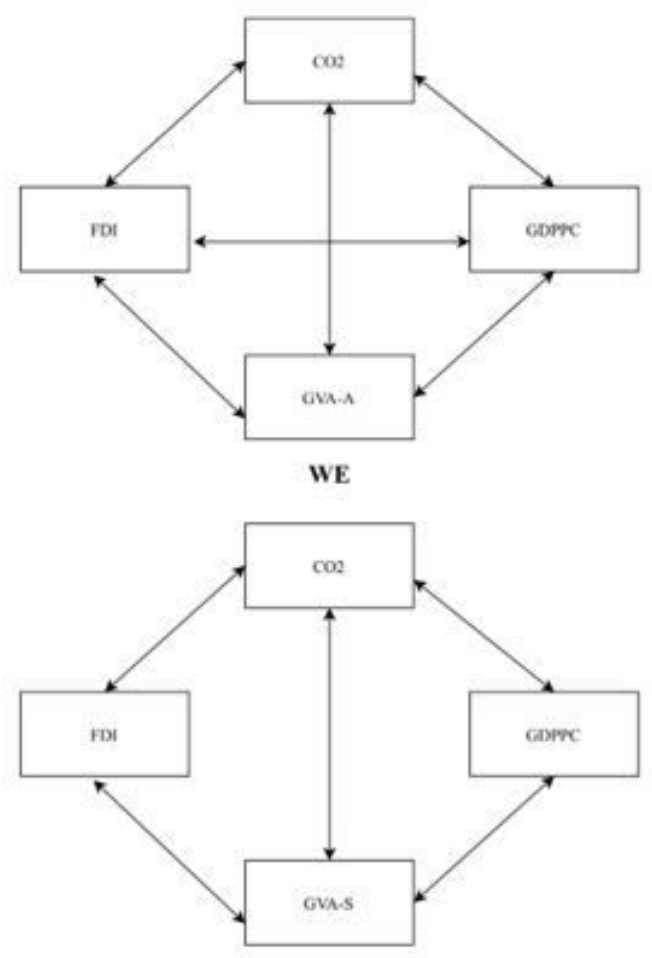

SE

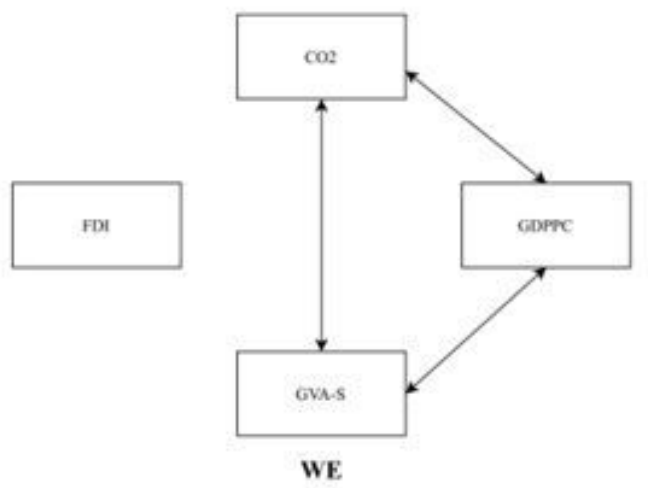

Figure 1

Relation summary of AGVAand SGVA. 

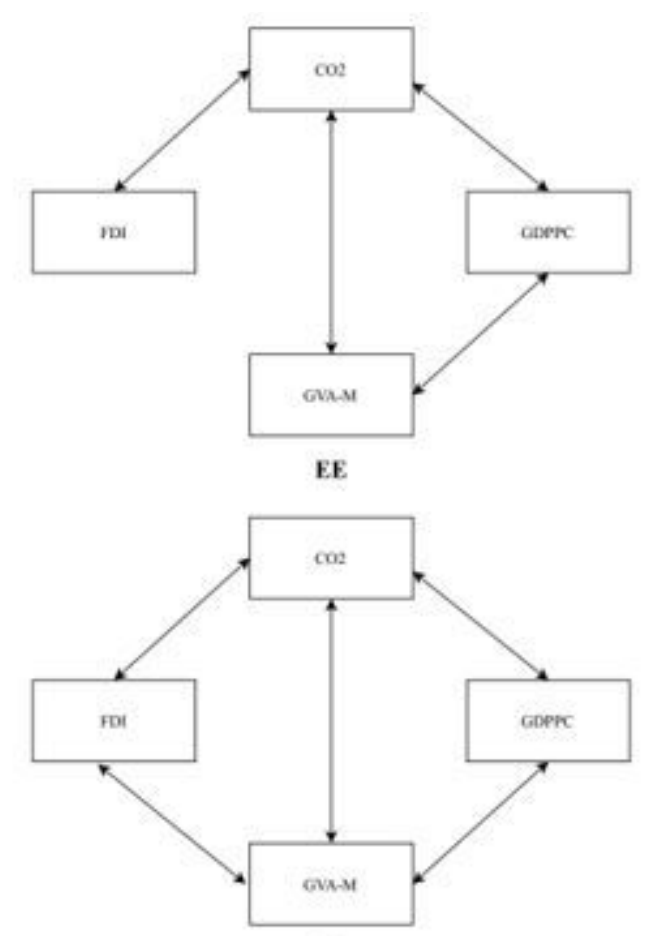

NE
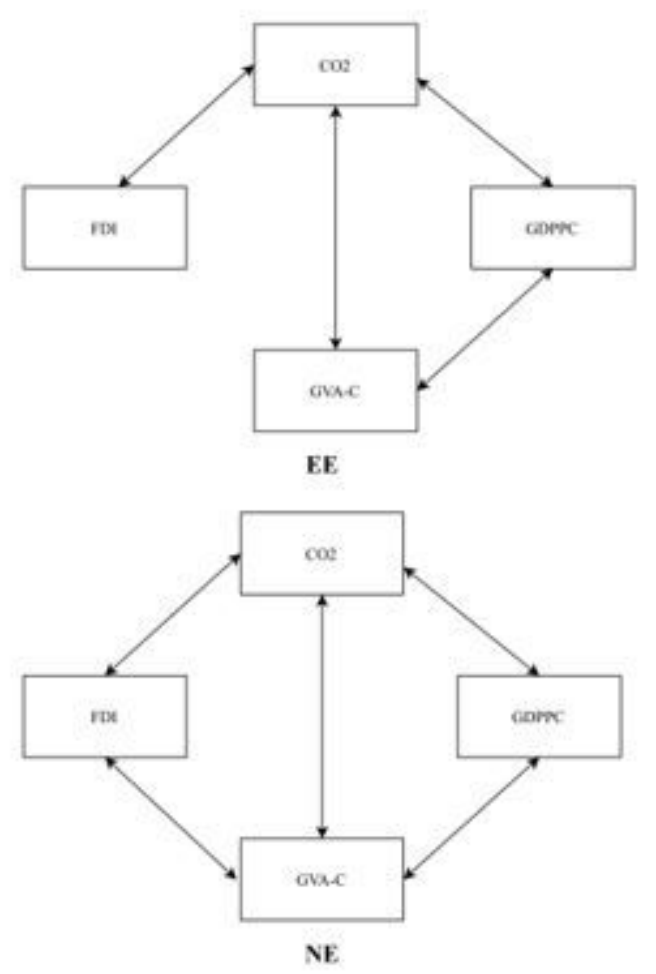
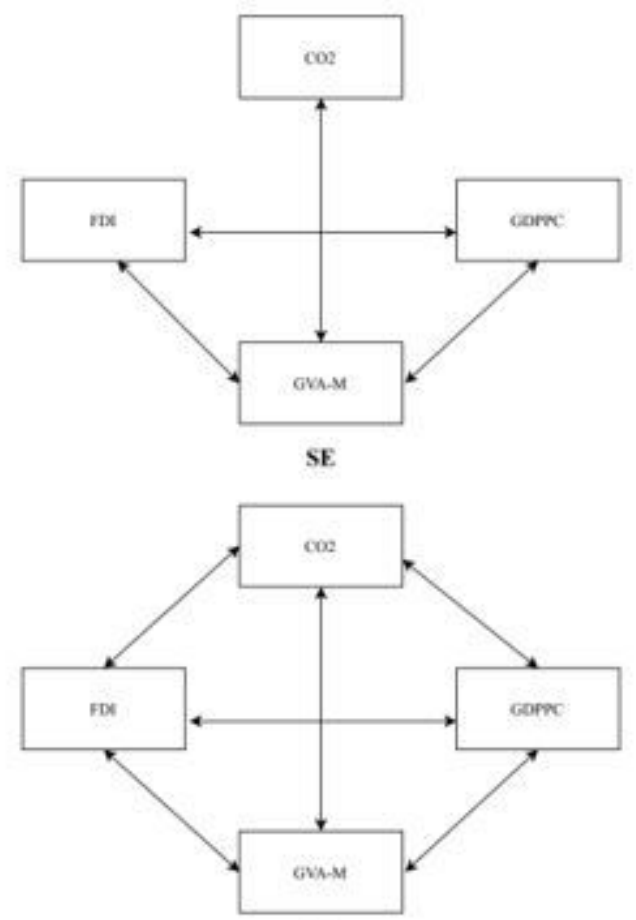

WE
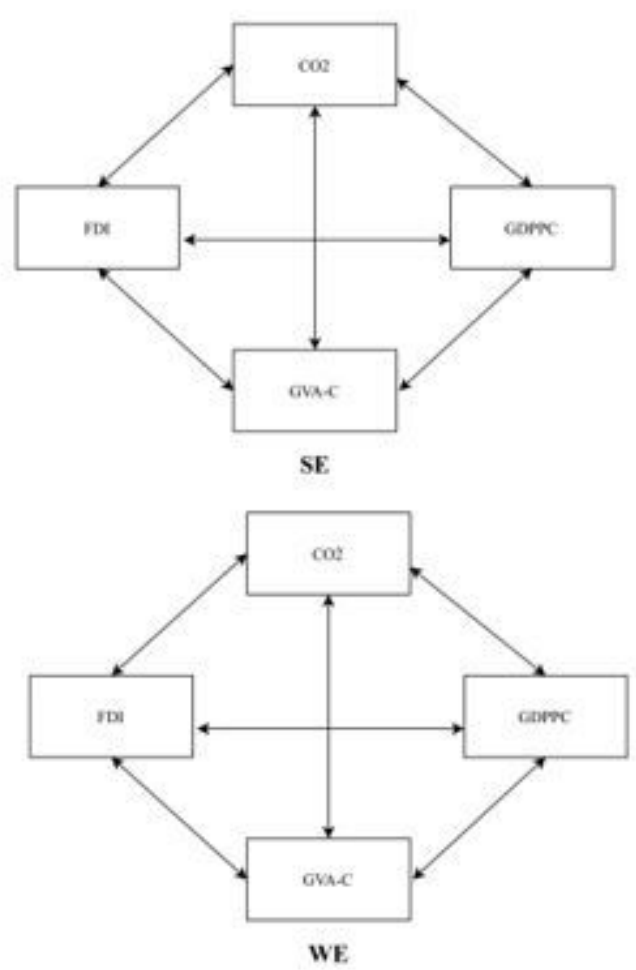

Figure 2

relation summary of MGVAand CGVA. 